\title{
Eliminating Conflicts of Interests in Banks: The Significance of the Volcker Rule
}

\author{
S. Burcu Avci, ${ }^{\dagger}$ Cindy A. Schipani ${ }^{\ddagger} \&$ H. Nejat Seyhun*
}

Public policy has been focused on controlling the conflicts of interests in banks for the last eighty-five years with limited success. Banks have a unique place in the economy as intermediaries between investors and companies, allowing them to obtain significant private, proprietary information. Public policy is focused on trying to ensure that banks do not misuse this information for their own benefit to the detriment of their clients. This is a tough task.

In this Article, we focus our attention more specifically on proprietary trading. We exploit a unique dataset that allows us to observe the information banks receive and what they do with it. When banks are hired as investment advisers, they become temporary insiders, and they are required to report all transactions in their client firms' stock to the SEC. Using this unique dataset, we analyze the kind of information banks acquire about their clients as part of their financial intermediary and advisory roles. Our data show that this information is highly valuable to banks. Specifically, banks have been able to earn more than $25 \%$ returns above market from proprietary trades on this information. Furthermore, after Glass-Steagall's prohibitions against commercial banks engaging in investment banking activities were relaxed, this return on investment rose to a whopping $40 \%$.

The Volcker Rule was enacted to aid in reducing systemic risks in the banking system and, among other purposes, to eliminate conflicts of interest that arise when banks profit at the expense of their clients. Scholars have previously argued that the Volcker Rule should be vigorously enforced to eliminate temptations to trade on material non-public information for banks' benefit and against their client's interest. We provide important empirical research for this proposition by showing that banks indeed trade on non-public information and earn higher than expected returns.

Indiana

$\dagger \quad$ Post-Doctoral Research Scholar, University of Notre Dame Law School, South Bend,

$\ddagger \quad$ Merwin H. Waterman Collegiate Professor of Business Administration and Professor of Business Law, University of Michigan, Ann Arbor, Michigan.

* Jerome B. \& Eilene M. York Professor of Business Administration and Professor of Finance, University of Michigan, Ann Arbor, Michigan. The authors wish to thank Zachary James, J.D. and William Schoof, Kathleen Knight, Weixin Li, and llya Mamin, J.D. Candidates, University of Michigan Law School, for helpful research assistance. 


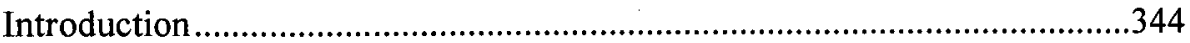

I. The Glass-Steagall Legislation: A Brief History ...................................347

A. Legislative History: The Pecora Commission ............................349

B. Glass-Steagall.................................................................. 350

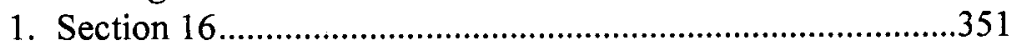

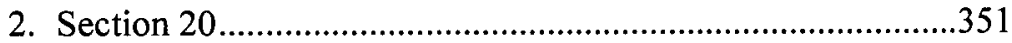

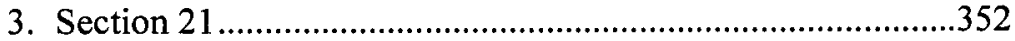

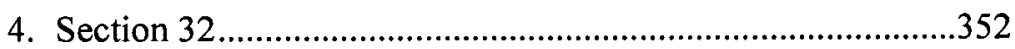

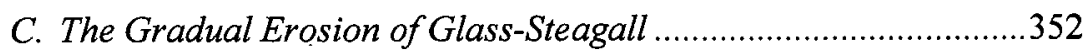

1. Immediate Loopholes.........................................................353

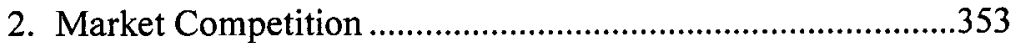

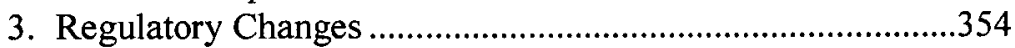

4. The Gramm-Leach-Bliley Act (GLBA) ...............................356

II. Conflicts of Interests and Attempts to Address the Legislative Gap.........358

A. The Conflict: Proprietary Trading .............................................358

1. Different Viewpoints on Bank Conflicts of Interest and Proprietary Trading ..........................................................358

2. Problems Associated with Proprietary Trading.....................359

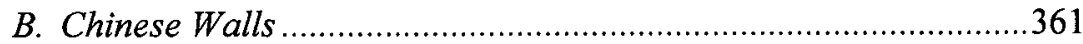

C. The Volcker Rule ..................................................................363

III. The Empirical Evidence of the Continuing Problem of Conflicts of Interest .368

Conclusion. .380

Introduction

In the banking sector, severe conflicts of interest can arise when, in the process of fulfilling their financial intermediary and adviser roles, bank executives become aware of opportunities to enter transactions for their own benefit that may also be detrimental to their banking clients. Examples of banking conflicts include the marketing and sale of banking products such as new securities and bank loans created with knowledge of material, non-public adverse information about their client firms. Conflicts involving banks are also 
evident in foreign exchange ${ }^{1}$ and LIBOR manipulation, ${ }^{2}$ the Enron ${ }^{3}$ and Madoff ${ }^{4}$ scandals, and banks' huge trading losses such as the London Whale trade. ${ }^{5}$

The original motivation for the Glass-Steagall Act, which restricted banks from underwriting new securities, was in part to control these potential conflicts. Specifically, it aimed to prevent banks from using the material, non-public, adverse information they acquire from normal banking activities in underwriting new securities. If banks realized that a particular client is in danger of financial distress, they would have an incentive to arrange for a new security sale to the public and use the proceeds of those sales to pay off the bank loans. ${ }^{6}$

The gradual weakening and subsequent repeal of most provisions of the Glass-Steagall Act in 1999 allowed commercial banks to acquire investment banking subsidiaries, grow substantially in size, and access even more information through more diverse banking activities. ${ }^{7}$ At the same time, proprietary trading became a major source of revenue for the banks. ${ }^{8}$

1. Large, international banks in different parts of the world colluded for at least a decade to rig exchange rates by front-running client orders and rigging the foreign exchange benchmark to gain financial benefits. See Philip Augar, How the Forex Scandal Happened, BBC NEWS (May 20, 2015), http://www.bbc.com/news/business-30003693 [http://perma.cc/T9WZ-J3XE]; Matt Levine, Banks Manipulate Foreign Exchange in Ways You Can't Teach, BLOOMBERG VIEW (Nov. 12, 2014, 7:15 PM), http:/www.bloomberg.com/view/articles/2014-11-12/banks-manipulated-foreign-exchange-in-waysyou-can-t-teach [http://perma.cc/8LZ9-JWHX].

2. The Wall Street Journal ran a story in April 2008 claiming that some banks understated their borrowing costs. Two years later, collusion was confirmed among the banks for the purpose of having LIBOR-related portfolios and making financial gains from these portfolios. See Carrick Mollenkamp, Bankers Cast Doubt on Key Rate amid Crisis, WALL ST. J. (Apr. 16, 2008, 12:01 AM), http://online.wsj.com/article/SB120831164167818299.html [http://perma.cc/PXZ3-573K].

3. Top management of Enron overstated financial performance by repackaging bank loans to appear as Enron's profits. Enron's bankruptcy swept away billions of dollars from investors' pockets and forced Congress to pass the Sarbanes-Oxley Act (SOX). See Enron Fast Facts, CNN (Apr. 23, 2018, 11:19 AM), http://www.cnn.com/2013/07/02/us/enron-fast-facts/index.html [http://perma.cc /KCQ2-KF4Q]; The Fall of Enron, BLOOMBERG BUSINESSWEEK (Dec. 17, 2001, 12:00 AM), http:// www,bloomberg.com/news/articles/2001-12-16/the-fall-of-enron [http:/perma.cc/8BLU-6MJR].

4. Banks enabled Bernie Madoff to create and perpetuate a Ponzi scheme that lasted for several years. See Stephanie Yang, 5 Years Ago Bernie Madoff Was Sentenced to 150 Years in PrisonHere 's How His Scheme Worked, BuS. INSIDER (Jul. 1, 2014, 6:54 PM), http://www.businessinsider.com how-bernie-madoffs-ponzi-scheme-worked-2014-7 [http://perma.cc/BA2A-G276].

5. Even though it was not a fraud, this incident is an example of bad risk management and its consequences on financial markets and investors. See Patricia Hurtado, The London Whale, BLOOMBERG QUICKTAKE (Feb. 23, 2016, 10:04 PM), http://www.bloomberg.com/quicktake/the-londonwhale [http://perma.cc/3L63-8KB9].

6. See Brett McDonnell, Don't Panic/ Defending Cowardly Interventions During and After a Financial Crisis, 116 PenN St. L. Rev. 1, 9 (2011) (noting that "distressed consumers and businesses default[ing] on loans, worsen[s] bank balance sheets").

7. See Heather Long, What the Heck is the Controversial Glass-Steagall Act?, CNN MONEY (Oct. 14, 2015, 1:57 PM), http://money.cnn.com/2015/10/14/investing/democratic-debate-whatis-glass-steagall-act/index.html [http://perma.cc/AWS4-886E] (discussing how the repeal in 1999 allowed banks to grow bigger); Julia Maues, Banking Act of 1933 (Glass-Steagall), FED. RES. BANK ST. LOUIS (Nov. 22, 2013), http://www.federalreservehistory.org/essays/glass_steagall_act [http://perma.cc/459PN4E4].

8. See, e.g., Imogen Rose-Smith, The End of Proprietary Trading May Hit Banks' Profits But Help Their Stock Prices, INSTITUTIONAL INV. (Dec. 30, 2010), http://www. 
The subsequent financial crisis of 2008 exposed another glaring weakness of banking in the post-Glass-Steagall era. Banks had grown too big, too risky, and too interconnected, with many surpassing trillions of dollars in assets, interbank loans, and liabilities on and off the balance sheet. The sheer size, risk, and interconnectedness of banking raised concerns about systemically important and too-big-to-fail banks. After numerous attempts to bring back Glass-Steagall failed, Congress attempted to contain systemic banking risk by passing the Volcker Rule, which prohibited proprietary trading, and enacting, through the Dodd-Frank Act, consumer protection and other ring-fencing and fire-wall provisions. ${ }^{9}$ The stated purpose of the Volcker Rule is as follows:

(1) to reduce risks to the financial system by limiting the ability of banks to engage in activities other than socially valuable core banking activities; (2) to protect taxpayers and reduce moral hazard by removing explicit and implicit government guarantees for high-risk activities outside of the core business of banking; and (3) to eliminate any conflict of interest that arises from banks engaging in activities from which their profits are earned at the expense of their customers or clients. ${ }^{10}$

To test the potential importance of the Volcker Rule, we would need to focus on proprietary trading, and we would need to know the amount of profits banks make from using proprietary adverse information about their clients. However, the source of the proprietary information banks use to execute their proprietary trading programs is typically confidential. Furthermore, banks do not disclose where and how they obtain this confidential information, which helps them create billions of dollars of profits every year.

In this Article, we investigate one possible source of this information. Specifically, we investigate the importance of the private information banks acquire as part of their financial intermediary and financial advisory role for their client firms. Banks often attain insider trading status and become subject to insider trading reporting requirements and trading restrictions when they are hired to provide financial advice to their client firms. When banks become temporary insiders, they must also report all these trades executed on Forms 3 , 4 , and 5 alongside other legal insiders. ${ }^{11}$

Using this insider trading database, we demonstrate that banks and other investment advisers can and do access important, private, material information

\footnotetext{
institutionalinvestor.com/Article/2741999/Markets-Regulation/The-End-of-Proprietary-Trading-MayHit-Banks-Profits-But-Help-Their-Stock-Prices.html\#.WVPm-YTytaQ [http://perma.cc/7T42-FXCB] (discussing the massive earnings the Goldman Sachs Group obtained through proprietary trading, noting that "the firm has demonstrated an uncanny ability to generate huge profits trading its own capital in everything from stocks and bonds to commodities, currencies and derivatives").

9. Dodd-Frank Wall Street Reform and Consumer Protection Act, Pub. L. No. 111-203, $\S 619,124$ Stat. $1376(2010)$ (codified as amended in scattered sections of 12 and 15 U.S.C.).

10. 21 st Century Glass-Steagall Act of 2017, H.R. 2585, 115 th Cong. (2017).

insider).

11. See Dirks v. SEC, 463 U.S. 646 (1983) (discussing the concept of the temporary
} 
about their clients and appear to trade on this information. On average, the inside information that banks and investment advisers acquire and trade on is highly valuable, allowing them to earn more on $25 \%$ on their proprietary trades. Furthermore, we find that relaxation and elimination of the Glass-Steagall restrictions allowed the banks and investment advisers to trade more frequently and earn a greater amount of abnormal profits. Since 2002, banks and other investment advisers appeared to have earned more than $40 \%$ abnormal profits from adverse information about their client firms. While previous scholars have argued that an added benefit of enforcing the Volcker Rule would be to eliminate the incentives to trade on material, non-public information about their clients by eliminating proprietary trading by banks, ${ }^{12}$ this Article provides important empirical support for this claim. In other words, our data supports the idea in the literature that enforcing the Volcker Rule would also help contain some of the current conflicts of interest in the banking system resulting from the elimination of Glass-Steagall restrictions.

What distinguishes our empirical analysis from previous studies is that our analysis is broader in scope and different in focus. For example, previous studies have focused on particular remedies, ${ }^{13}$ or on a different source of conflicts of interest. ${ }^{14}$ Our study examines illicit behavior connected to proprietary trading and illustrates that it is a widespread problem that could be solved by rigorous application of the Volcker rule.

This Article is organized as follows. Part I presents a brief history of the Glass-Steagall Act, including a discussion of its subsequent erosion. In Part II, we discuss the conflicts of interest presented by proprietary trading and analyze current mechanisms addressing conflicts, focusing in particular on Chinese Walls and the Volcker Rule. We then present our empirical analysis in Part III which provides evidence that conflicts of interest are alive and well. That is, the temptation for banks is too great, and they indeed trade on the confidential, inside information obtained from their clients. This Part thus highlights the need for regulation to decrease the conflicts of interest inherent in proprietary trading through strong enforcement of the Volcker Rule. Recommendations and concluding remarks follow.

\section{The Glass-Steagall Legislation: A Brief History}

In order to illustrate why rigorous enforcement of the Volcker rule is necessary to reduce the harms caused by conflicts of interest and proprietary

12. See infra note 108 .

13. See, e.g., H. Nejat Seyhun, Insider Trading and the Effectiveness of Chinese Walls in Securities Firms, 4 J. L. ECON. \& POL'Y 369, 386 (2008) (examining the effectiveness of "Chinese Walls" to combat conflicts of interest).

14. See, e.g., id. at 370 n.3 (discussing previous studies looking at conflicts of interest between bonds and analysts). 
trading, context is important. This Part gives context to the key historical and policy developments that led to the enactment of the Volcker Rule.

Buttressed by skyrocketing unemployment, plummeting stock valuations, evidence of securities manipulation and outright fraud, the Great Depression served as the motivating force for the foundational legislation of the securities, finance, and banking industries. Acts such as the Securities Act of $1933^{15}$ and the Exchange Act of $1934^{16}$ have become the cornerstones of the world-leading U.S. financial system. One such cornerstone act, known as the Glass-Steagall Act, ${ }^{17}$ has been gradually torn down by market forces, even though the problems it aimed to remedy still exist today.

Before the Glass-Steagall legislation and the accompanying financial and securities reforms, there was little federal regulation of the banking industry. ${ }^{18}$ The Office of Comptroller of the Currency was not created until 1864 and then only had authority over national banks, which many were not. ${ }^{19}$ Market forces kept commercial banks from expanding into investment banking. ${ }^{20}$ Savings and loan (S\&L) institutions largely focused on long-term securities and mortgages as well as taking small deposit amounts. ${ }^{21}$ After the Civil War, the U.S. banking system extended a divide between commercial and investment banking. ${ }^{22}$

Then came the Great Depression. Following the stock market crash in 1929 and through 1933, U.S. GDP fell by $30 \%$, unemployment soared to $25 \%$, the stock market dropped $80 \%$, and over 7,000 banks failed..$^{23}$ Bank depositors lost almost $\$ 400$ million, the equivalent of over $\$ 5.6$ billion in 2017 dollars. $^{24}$

The Glass-Steagall Act prohibited commercial banks from engaging in either investment banking or nonbanking activities in an effort to both limit unsafe speculation by banks with consumers' funds as well as prevent self-

15. Securities Act of 1933 , ch. 38 , title I, $\S 1,48$ Stat. 74 (1933) (codified as amended at 15 U.S.C. $\S 77(2018)$ ).

16. Securities Exchange Act of 1934, ch. 404, $₹ 1,48$ Stat. 881 (1934) (codified as amended at 15 U.S.C. $\$ 78(2018)$ ).

17. Banking Act of 1933 , Pub. L. No. $73-66,48$ Stat. 162 (1933) (codified as amended in scattered sections of 12 U.S.C.).

18. James R. Barth et al., Bank Regulation in the United States, 56 CESIFO ECON. STUD. $112,114-19(2010)$.

19. Id. at 5 .

20. Id.

21. Id.

22. Michelle Clark Neely, Commercial \& Investment Banking: Should this Divorce be Saved?, REGIONAL ECONOMIST (1995), http://www.stlouisfed.org/publications/regional-economist/april1995/commercial--investment-banking-should-this-divorce-be-saved [http://perma.cc/U2XF-EYZD].

23. David C. Wheelock, The Great Depression: An Overview, FED. RES. BANK ST. LouIS $\quad \mathrm{xi}, \quad$ http:/www.stlouisfed.org/ /media/Files/PDFs/Great-Depression/the-great-depressionwheelock-overview.pdf [http://perma.cc/WZN6-MND5].

24. See James Lardner, A Brief History of the Glass-Steagall Act, DEMOS 1 (Nov. 10, 2009), http://www.demos.org/publication/brief-history-glass-steagall-act [http://perma.cc/8NBT-ATUU] (assuming the annual inflation rate was $3.05 \%$ from 1929 to 2017). 
dealing and conflicts of interest. ${ }^{25}$ Commercial banks could not affiliate with investment banks. ${ }^{26}$ Regarding securities, "[ $\left.t\right]$ he Glass-Steagall Act accordingly gave banks a year to decide: they could get out of the securities business, and enjoy the benefits of deposit insurance and access to the low-interest credit of the Federal Reserve; or they could be investment banks and brokerage houses, [and] forego those privileges."27

The gradual weakening and subsequent partial repeal of Glass-Steagall in 1999 by the Gramm-Leach-Bliley Act $^{28}$ allowed commercial banks to merge with investment banks, enabling these financial conglomerates to grow in size substantially. Further, investment activities grew in importance to commercial banks. Such increased importance bred conflicts of interest; to prevent these conflicts from negatively affecting consumers, the SEC mandated the creation of so-called "Chinese Walls" within the firms, which refers to complete separation of personnel, decision-making, and compensation between conflicted departments.

The subsequent financial crisis of 2008 highlighted the shortcomings of these Chinese Walls. Although somewhat effective, they did not adequately replace Glass-Steagall's now-removed conflict of interest protections. In 2010, after numerous attempts to reinstate Glass-Steagall failed, Congress attempted to remedy the conflicts of interest inherent in universal banking by passing the Volcker Rule, as well as enacting other consumer protections and ring-fencing and fire-wall provisions in the Dodd-Frank Act. ${ }^{29}$

The next section begins with a brief overview of the history of the GlassSteagall legislation, followed by the relevant provisions of the statute relating to banking conflicts of interest. It continues with a discussion of the forces leading to the gradual demise of Glass-Steagall, concluding with an overview of the Gramm-Leach-Bliley Act.

\section{A. Legislative History: The Pecora Commission}

Appointed as chief counsel to the U.S. Senate's Committee on Banking and Currency, New York District Attorney Ferdinand Pecora led a media-frenzied Congressional inquiry of Wall Street. ${ }^{30}$ The hearings, taken at the height of the

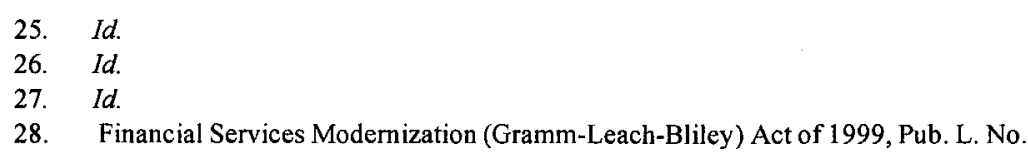
106-102, 113 Stat. 1338 (codified as amended in scattered-sections of 15 U.S.C.)

29. See Christoph Kumpan \& Patrick C. Leyens, Conflicts of Interest of Financial Intermediaries: Towards a Global Common Core in Conflicts of Interest Regulation, 5 EUR. CORP. FIN. L. REV. 72, 74 (2008) (noting that financial intermediaries "serve as a device for securing capital market stability").

30. Bill Moyer, Bill Moyer's Journal Transcript Part II, PBS (Apr. 24, 2009), http://www.pbs.org/moyers/journal/04242009/transcript1.html [http://perma.cc/EW2Z-HTV8]. 
Great Depression and alongside the infamous mandatory four-day banking holiday, uncovered actions of the bankers that built on existing public outrage. A Chase National Bank executive had shorted his company's stock, and National City Bank packaged failed loans as securities and sold them off to unknowing investors. ${ }^{31}$ Charles Mitchell sold discounted stocks to a family member to avoid paying taxes. ${ }^{32}$ The J.P. Morgan Bank maintained a "preferred list" of powerful businessmen to whom it would provide favors and offer securities at below market prices. ${ }^{33}$ Jack Morgan paid no income tax in 1921,1922 , or $1923 .^{34}$ The populist outrage stirred up by the Pecora Commission compelled Congress and the President to action and resulted in the passage of the Glass-Steagall Act. ${ }^{35}$

\section{B. Glass-Steagall}

The statute states three purposes:

1) To provide for safer and more effective use of bank assets;

2) To limit stock market speculation; and

3) To prevent self-dealing and conflicts of interest. ${ }^{36}$

As the Court elaborated in Investment Co. Institute v. Camp, Congress was concerned with the "promotional interest of the investment banker and the obligation of the commercial banker to render disinterested investment advice." ${ }^{\prime 37}$ The interests of the commercial and investment banker could often be in conflict. The commercial banker was entrusted with government insured funds while the investment banker often looked to sell securities, which could be purchased with those funds.

31. Lardner, supra note 24.

32. Subcommittee on Senate Resolutions 84 and 234 (The Pecora Committee), U.S. SENATE, http://www.senate.gov/artandhistory/history/common/investigations/Pecora.htm [http://perma .cc/5R3S-EPL9]. In almost poetic fashion, Charles "Sunshine" Mitchell, who entered the Pecora hearings surrounded by throngs of attorneys and support staff, exited ten days later abandoned and alone. He resigned shortly thereafter. Michael A. Perino, Ferdinand Pecora: The Hellhound of Wall Street, 21 EXPERIENCE 15, 18-19 (2011).

33. Bonnie James, It's Past Time for a New Pecora Commission, 39 EXECUTIVE INTELLIGENCE REV. 12, 12 (2012). This preferred list contained multiple presidents, treasury secretaries, and chairman of both the Democratic and Republican national committees and many other politicians. See Alexander Tabarrok, The Separation of Commercial and Investment Banking: The Morgans vs. The Rockefellers, 1 Q. J. AuSTRIAN ECON. 1, 3 (1998).

34. See James, supra note 33, at 15 . Chase National Bank voluntarily separated their investment and commercial banking practices in early 1933, likely easing industry pushback to GlassSteagall. See, e.g., K. Sabeel Rahman, Democracy and Productivity: The Glass-Steagall Act and the Shifting Discourse of Financial Regulation, 24 J. POL'Y HIST. 612, 618 (2012).

35. Banking Act of 1933, Pub. L. No. 73-66, 48 Stat. 162 (1933) (codified as amended in scattered sections of 12 U.S.C.).

36. Id.

37. Inv. Co. Inst. v. Camp, 401 U.S. 617,663 (1971) 
Glass-Steagall is found in Sections 16, 20,21, and 32 of the much broader Banking Act of $1933 .{ }^{38}$ Coming in as a part of FDR's New Deal and alongside the 1933 Securities Act and the 1934 Exchange Act, the Banking Act of 1933 also established federal deposit insurance, increased Federal Reserve oversight over national banks, created the Federal Open Market Committee (FOMC), and introduced Regulation Q's predecessor, which outlawed the payment of interest rates on checking accounts and gave the Federal Reserve the power to set caps on interest paid on other deposits. ${ }^{39}$

\section{Section 16}

Section 16 limits national commercial banks to exercising "all such incidental powers as shall be necessary to carry on the business of banking." ${ }^{940} \mathrm{It}$ also outlaws underwriting and limits dealing in investment securities to nonrecourse brokerage activities on behalf of clients. ${ }^{41}$ However, these prohibitions were never an impenetrable firewall that completely separated investment and commercial banking. Section 16 granted the OCC the power to allow banks to trade up to $15 \%$ of their capital stock and $25 \%$ of their surplus funds for their own account, up to the lesser of $10 \%$ or $\$ 100,000$ in any one security. ${ }^{42}$ Section 16 also contained a carve-out for "bank-eligible securities," at the time obligations of the United States, the States or any political subdivision of either. ${ }^{43}$

\section{Section 20}

Section 20 prohibited commercial, member bank affiliates from "engag[ing] principally in the issue, flotation, underwriting, public sale, or distribution ... securities. ${ }^{944}$ Violations resulted in ongoing fines and eventual discontinuation of privileges granted to banks through the Federal Reserve System. ${ }^{45}$

38. Banking Act of $1933 \S \S 16,20,21,32$; DAVID H. CARPENTER ET AL., CONG. RES. Serv., R.44349, The Glass-Steagall ACt: A Legal and POliCy ANAlysis 13 (2016).

39. Julia Maues, Banking Act of 1933 (Glass-Steagall), FED. RES. HIST. (Nov. 22, 2013), http://www.federalreservehistory.org/Events/DetailView/25 [http://perma.cc/RP5T-Q3RV]. Although Glass was the driving force behind Glass-Steagall, the then chairman of the House Banking and Currency Committee, Henry Steagall, agreed to sponsor the bill if the creation of deposit insurance was included. Id. Glass was opposed to the creation of deposit insurance. Michael Perino, What FDR Hated About Glass-Steagall, BLOOMBERGVIEW (June 14, 2013), http:/www.bloomberg.com/view/articles /2013-06-14/what-fdr-hated-about-glass-steagall [http://perma.cc/5Y23-ZAKM].

40. Banking Act of $1933 \S 16$.

41. Id.

42. Id. Banks were given one year to come into compliance with Glass-Steagall. Id.

43. Id.

44. Id. $\$ 20$. Sections 20 's "principally engaged" language left enough ambiguity that banks occasionally acquired affiliates engaged in some prohibited activities, but not enough to make the acquisitions prohibited. By 2000 there were fifty-one of these "Section 20 Affiliates."

45. Id. 


\section{Section 21}

As the inverse to Section 20, Section 21 made it illegal for investment banks to engage in deposit taking. ${ }^{46}$ Qualifying deposits were only demand deposits; those "subject to check or to repayment upon presentation of a passbook, certificate of deposit, or other evidence of debt, or upon request of the depositor. $^{47}$

\section{Section 32}

Section 32 banned officers and directors of commercial, Federal Reserve member banks from being an officer, director or manager of an "organization engaged primarily in the securities business . . ."48 It also largely disallowed member banks from dealing with non-member banks that would be in violation of this section if they were a member without prior Federal Reserve permission.

\section{The Gradual Erosion of Glass-Steagall}

Glass-Steagall's divide began to erode almost immediately after its enactment. Competitive forces between investment, commercial, and international banks, as well as regulatory arbitrage and turf battles, caused regulators and the Judiciary to alter the Act without evidence that the underlying problems motivating the Act had dissipated; these actions were taken without (and sometimes against) evidence of legislative intent. ${ }^{49}$

46. Id, §21.

47. Id. Section 30 also contained a prohibition on any entity or person from taking demand deposits unless subject to Federal Reserve or Office of the Comptroller of the Currency (OCC) oversight. See id. $\$ 30$.

48. Id. §32. Although the intent was not to break up "too-big-to-fail" banks, it had that immediate effect. JP Morgan spun off Morgan Stanley as a stand-alone investment banking entity shortly after its passage. CARPENTER ET AL., supra note 38, at 8.

49. There seemed to be a number of misconceptions around the Glass-Steagall Act. For example, consider the following: Critics claimed that it was wrong to assume that a bank's securities activities had much to do with insolvencies in the 1930 s, but different provisions of the Banking Act were meant to prevent future insolvencies. Don More, The Virtues of Glass-Steagall: An Argument Against Legislative Repeal, 1991 CoLUM. BuS. L. REV. 433, 440-41 (1991). The Glass-Steagall Act, on the other hand, was enacted "specifically to protect the securities markets from the destabilizing effect of commercial banks, rather than the other way around." Id. at 442 . Thus:

The key causation question therefore is not whether the banking industry's problems in the 1930 s were caused by commercial bank involvement in securities activities, but whether securities speculation was encouraged by such involvement. As to. the latter question, it is beyond doubt that commercial banks' heavy diversion of depositors' funds into securities was the major factor behind the disastrous run-up in the stock market.

Id. at 443 . 


\section{Immediate Loopholes}

Because Glass-Steagall put no legal restrictions on activities conducted by entities that owned commercial banks, bank holding companies (BHCs) were immediately utilized as a loophole to the Act's restrictions. ${ }^{50} \mathrm{By}$ incorporating under a BHC, banks could enjoy much of the benefits of being an investment bank without running afoul of Glass Steagall while also creating the relationships and conflicts the Act aimed to remedy. ${ }^{51}$ By 1938, numerous Senators (including Senator Glass) and President Franklin D. Roosevelt called for further regulation or prohibition of BHCs. ${ }^{52}$ This regulation did not come about until the 1956 Bank Holding Company Act, which, among other things, limited the nonbanking companies a BHC could own to those "so closely related to the business of banking or of managing or controlling banks as to be a proper incident thereto ..." ."53 But the 1956 Act did not eliminate the loophole completely. It was not until the 1970 amendments to the Bank Holding Company Act that this loophole was finally closed. ${ }^{54}$

\section{Market Competition}

Outside competitors encroaching on commercial banking activities often led to the loosening of Glass-Steagall based regulations. As lightly regulated nonbanks competed with banks, their unequal treatment often seemed unjustified. In response, the stricter regulator often loosened its policies to stem the exit of constituent entities to the more lucrative form despite no evidence or legislative signal that the risks the Act was originally aimed at mitigating no longer existed.

In response to increasing interest rates and asset/liability maturity mismatch in the savings and loan (S\&L) industry, in 1982, after $118 \mathrm{~S} \& \mathrm{~L}$ institutions failed and 752 merged, 418 S\&L institutions with assets of $\$ 220$ billion were still

50. Saule T. Omarova \& Tahyar E. Margaret, That Which We Call a Bank: Revisiting the History of Bank Holding Company Regulations in the United States, 31 REV. BANKING \& FIN. L. 113, 121 (2012).

51. See id. ("The Glass-Steagall Act of 1933, which prohibited banks from participating in the securities dealing and underwriting business and from affiliating with securities firms, otherwise did not impose any specific legal restrictions on the activities of business entities that owned or controlled commercial banks.").

52. Glass Moves to End Bank Holding Firms, CHI. DAILY TRIB. (Jan. 25, 1938), http:/archives.chicagotribune.com/1938/01/25/page/2 1/article/glass-moves-to-end-bank-holding-firms [http://perma.cc/WD6F-ZPFB]. The Federal Reserve had spoken out against bank holding companies as early as 1927 . Omarova \& Margaret, supra note 50, at 132-33.

53. Bank Holding Company Act of 1956, Pub. L. No. 84-511, $\S 4(\mathrm{c})(6), 70$ Stat. 133, 137 (codified as amended at 12 U.S.C. $\$ 1841$ et seq. (2018)).

54. See Omarova \& Margaret, supra note 50, at 146. In Congressional hearings leading up to the amendment, the Federal Reserve Board noted that "there [was] less need for concem of preferential treatment in extending credit where no commercial loans [were] involved." Id. at 137. 
insolvent. ${ }^{55}$ This insolvency, combined with subsequent government bailouts, led regulators to revise the $S \& L$ regulatory regime and loosen their restraint on the sector. In turn, these actions increased competition between S\&L institutions and banks. ${ }^{56}$ In July of 1982 , S\&Ls were allowed to amortize goodwill in mergers over forty years, instead of the ten years allowed previously, taking the regulators off the hook for what would be otherwise insolvent banks and grossly overstating the actual value of otherwise insolvent institutions. ${ }^{57}$

S\&Ls grew rapidly after these changes, ${ }^{58}$ which affected the competitiveness and profitability of banks in a multitude of ways. Both sectors directly competed for depositors' funds, increasing their costs of capital which S\&Ls needed less. ${ }^{59}$ Inexperienced and unskilled S\&L institutions, flush with cash and unrestricted in their practices, also competed with commercial banks in issuing loans. ${ }^{60}$

Competitive pressures from abroad, most notably Europe, Japan, and Canada, played a role in gradually spurring the expansion of banking powers. ${ }^{61}$ These foreign institutions could often operate more broadly in the U.S. than domestic banks, putting the domestic banks at a competitive disadvantage. ${ }^{62}$

\section{Regulatory Changes}

Regulatory turf battles, driven by both domestic and international competitive marketplace forces and political dealings among, for the most part, (1) the Federal Reserve Board (FRB) as the regulator of bank holding companies and state banks that are members of the Federal Reserve System, ${ }^{63}$ (2) Office of

55. The Savings and Loan Crisis and Its Relationship to Banking, in 1 HISTORY OF THE EIGHTIES - LESSONS FOR THE FUTURE 168-69 (1997). The ordeal is sometimes referred to as the "S\&L Debacle." Id.

56. Id. at 184.

57. Fed. Res. Bank of S.F., FRBSF Weekly Letter: S\&L Accounting, FED. RES. BANK ST. LOUIS 2 (Dec. 21, 1984), http://fraser.stlouisfed.org/files/docs/historical/frbsf/frbsf_let/frbsf_let_ 19841221.pdf [http://perma.cc/X4YE-EZG8]. Relaxation of investor control limits also were lifted in an effort to attract new capital to the industry. FED. DEPOSIT INS. CORP., infra note 71, at 175.

58. FED. DEPOSIT INS. CORP., infra note 71 , at 178.

59. See id. at $\mathbf{1 8 1}$ (noting that "accounting distortions favored high-growth S\&Ls that continued to report healthy returns on assets and regulatory net worth .... [and] the bidding up of deposit interest rates by aggressive and/or insolvent S\&Ls increased the cost of funds, [was] adversely affecting both commercial banks and conservatively run thrifts").

60. See id. (" $[\mathrm{B}]$ anks were negatively influenced by the entrance of inexperienced and, in some cases, rogue S\&Ls into commercial and real estate lending.").

61. See William D. JaCKSON, CONG. Res. SERV., IB87061, Glass-STEaGall ACT: COMMERCIAL VS. INVESTMENT BANKING (1987) (discussing the impact foreign banks had on financial reforms within the U.S.).

62. Id.

63. Mark Jicking \& EdWard V. MurPhy, CONG. Res. SERV., R43087, Who REGULATES WHOM? AN OVERVIEW OF U.S. FINANCIAL SUPERVISION 23 (2009). The Dodd-Frank Act expanded the FRB's power to other institution types but such a discussion is beyond the scope of this historical recounting. 
Comptroller of the Currency (OCC) as the regulator of national banks, (3) U.S. federal branches of foreign banks and federally chartered thrift institutions, ${ }^{64}$ and (4) the Securities Exchange Commission (SEC), which regulates brokers, dealers, clearing agencies, mutual funds and investment advisers ${ }^{65}$ greatly contributed to the erosion of the Glass-Steagall commercial-investment bank barrier.

In 1937, the FRB revised Regulation $F$, which provided rules for bank-run common-trust funds, which are pooled funds of small trusts held and administered by a bank and exempt from the reporting requirements of the otherwise applicable Investment Company Act of $1940{ }^{66}$ The SEC originally refrained from combatting this expansion because the FRB prevented commontrust funds from being used solely as a device for collective investment. ${ }^{67} \mathrm{After}$ a 1962 statutory shift in power, the OCC amended Regulation $\mathrm{F}$ with Regulation 9, eliminating this FRB limitation. The SEC finally pushed back on this infringement of their regulatory territory. ${ }^{68}$ In Investment Co. Institute v. Camp, the Supreme Court ruled that this expansion of power was outlawed by GlassSteagall when it was used to both pool and manage trust funds. ${ }^{69}$ Banks could manage clients' funds and pool clients' funds, but not in conjunction with each other. ${ }^{70}$

In the 1970s and 1980s, the regulators' language marked a shift away from maintaining the Glass-Steagall wall to a debate over the proper regulatory regime. In 1972, the FRB amended Regulation Y to include "serving as investment adviser ... to an investment company ... so closely related to banking ... as to be a proper incident thereto" and therefore be deemed a permissible BHC affiliate activity. ${ }^{71}$ In 1957, the OCC allowed banks to profit from brokerage transactions provided on behalf of their existing customers only.$^{72}$ However, the OCC expanded this interpretation in 1982 to allow national banks to offer discount brokerage services to both customers and noncustomers. $^{73}$ In 1983, the FRB enlarged its regulatory reach by including retail

64. Id

65. Id. at $15-16$.

66. Comment, Regulation of Bank-Operated Collective Investment Funds-Judicial or Legislative Resolution of an Administrative Controversy?, 73 YALE L.J. 1249, 1250-51 (1964).

67. Id. at 1251

68. Id. at $1251-52$

69. 401 U.S. 617.

70. Id. at $624-25$.

71. FDIC Law, Regulations, Related Acts: 7500 - FRB Regulations, FED. DEPOSIT INS. CORP., http://www.fdic.gov/regulations/laws/rules/7500-3900.html [http://perma.cc/2LCL-7W9M].

72. Philip Wallach, Policy Erosion and Policy Maintenance: The Case of Glass-Steagall (Nov. 24, 2008) (unpublished manuscript), http://lapa.princeton.edu/sites/default/files/Wallach_LEGS_ Paper.pdf [http://perma.cc/MW38-UZ78].

73. Intuit Inc. Elec. Fin. Servs. Council, Promoting Efficient Arrangements Between Portals and Online Brokers, U.S. SEC. \& EXCHANGE COMMISSION 6 (June 2000), http://www.sec.gov /pdf/intuitefscpaper.pdf [http://perma.cc/T2F9-ER9L] 
securities brokerages, engaged solely in buying and selling of securities on behalf of clients without giving investment advice as "so closely related to banking . . . as to be a proper incident thereto." " In what some saw as an apparent conflict with the legislative text, the FRB ruled in 1986 that a commercial bank could derive up to $5 \%$ of its gross revenues from investment banking. ${ }^{75}$ In 1996 , this limit was raised to $25 \%$, virtually rendering Glass-Steagall's wall moot. ${ }^{76}$

\section{The Gramm-Leach-Bliley Act (GLBA)}

The erosion of what was left of Glass-Steagall's divide picked up speed in the 1990s. By 1999, 70\% of banks offered insurance products. ${ }^{77}$ In 1998 , Citigroup Bank and Travelers Insurance proposed what at the time was the largest corporate merger; creating the largest financial institution ever, in blatant violation of Glass-Steagall. ${ }^{78}$ No regulator staged complete resistance to the merger. They only threatened requiring possible divestitures. After these threats, Citi and Travelers joined an already existing movement and strongly lobbied for a repeal of Glass-Steagall. ${ }^{79}$ It came about in the Financial Modernization Act of 1999 , commonly known as the GLBA. ${ }^{80}$

The GLBA, signed into law by President Bill Clinton, was enacted with the intention of promoting the benefits of financial integration while still safeguarding the soundness of the financial system. This final part was an acknowledgement of the continuing risks Glass-Steagall aimed to remedy. ${ }^{81}$ The

74. Sec. Indus. Ass'n v. Bd. of Governors of Fed. Reserve Sys., 468 U.S. 207, 210, 215 (1984) (quoting 12 U.S.C. $\S 1843(\mathrm{c})(8))$.

75. Matthew Sherman, A Short History of Financial Deregulation in the United States, CTR. ECON. \& POL'Y RES., at 9 (July 2009), http://cepr.net/documents/publications/dereg-timeline-200907.pdf [http://perma.cc/7ALM-E24H].

76. Id.

77. Jerry W. Markham, The Subprime Crisis: A Test Match for the Bankers: GlassSteagall vs. Gramm-Leach Bliley, 12 U. PENN. J. BUS. L. 1081,1102 (2010). Alan Greenspan, then Chairman of the Federal Reserve, openly championed the demise of Glass-Steagall because he believed the law would negatively affect the United States' position in the financial world. His views did recognize that the conflicts of interest Glass-Steagall aimed to remove still existed, though. He believed a bank's banking and securities activities needed to be kept at arms-length in any future legislation. Hugh Vickery, Greenspan Warns Congress of Glass-Steagall, UNITED PRESS INT'L (Nov. 18, 1987), http://www.upi.com/Archives/1987/11/18/Greenspan-warns-Congress-of-Glass-Steagall /1253564210000/ [http://perma.cc/Q97L-5EQ5].

78. Lardner, supra note 24 , at 2.

79. Id.

80. Gramm-Leach-Bliley Act, Pub. L. No. 106-102, 113 Stat. 1338 (1999) (codified as amended in scattered sections of 15 U.S.C.); Lardner, supra note 24, at 2 . Citi and Travelers merged shortly after GLBA but separated when Travelers was spun off in 2002. Keisha Lamothe, Travelers Buys Back Its Red Umbrella, CNN MONEY (Feb. 13, 2007), http://money.cnn.com/2007/02/13/news /companies/citigroup/?postversion=2007021314 [http://perma.cc/9HYE-CDGQ]. Gramm had been introducing variants of the GLBA since before 1995. After leaving government, Gramm went to work for UBS AG. Lardner, supra note 24, at 3.

81. See Joe Mahon, Financial Services Modernization Act of 1999, Commonly Called Gramm-Leach-Bliley, FED. RES. HIST. (Nov. 12, 1999), http://www.federalreservehistory.org/Events 
GLBA aimed to allow U.S.-based banks to operate as universal banks. To do this, the GLBA created the financial holding company (FHC), an evolution of the $\mathrm{BHC}$ that allowed commercial and investment banks to be owned by the same holding company. ${ }^{82}$ Cross-marketing restrictions prevented banks from marketing the products and services of other entities within the holding company. ${ }^{83}$ The GLBA also eliminated the commercial/investment bank affiliation restrictions contained in Sections 20 and 32 of the GSA. ${ }^{84}$ A national bank could now engage in financial activities through a subsidiary so long as the financial subsidiary does not exceed the lesser of $\$ 50$ billion or $45 \%$ of the bank's assets. ${ }^{85}$ State member banks could control a subsidiary engaging in all the activities allowed a subsidiary of a national bank. With FDIC approval, they could also engage as principals in numerous activities not allowed to be conducted by national banks. ${ }^{86}$

Still, the GLBA did not eliminate Glass-Steagall completely. Sections 16 and 21 largely continued the restriction on activities carried on within subsidiaries. ${ }^{87}$ National banks still could not engage in insurance underwriting, merchant banking, insurance company portfolio investments, real estate development, or real estate investment. ${ }^{88}$ Along with this internal divide, the GLBA also attempted to account for at least some of the conflicts of interest that could arise under this new structure. In addition, personal information of consumers can only pass from banking subsidiaries (or be shared with third parties) if the consumer is advised of the practice and has the option to opt out of some sharing of personal information. ${ }^{89}$ However, these Glass-Steagall remnants are almost wholly ineffective.

Despite the continued existence of conflicts of interests, the GLBA does nothing to address them. In the absence of Glass-Steagall, it thus becomes critical that this gap be addressed. Part II follows with a discussion of the conflicts of interest presented by proprietary trading and the role of the Volcker Rule in diminishing the conflicts.

/DetailView/53 [http://perma.cc/KT69-LNZY] (discussing changes implemented by the Gramm-LeachBliley Act).

82. Id.

83. Id.

84. Financial Services Modernization Act-Gramm-Leach-Bliley-Summary of

Provisions, FED. FIN. INST. EXAMINATION COUNCIL (2016), http://www.ffiec.gov/exam/InfoBase /documents/02-con-g-1-b_summary_of_provisions-010416.pdf [http://perma.cc/57N3-KKTV].

85. Id.

86. Abdullah Al Mamun et al., The Impact of the Gramm-Leach-Bliley Act on the Financial Services Industry, 28 J. ECON. \& FIN. 333, 335 (2004).

87. CARPENTER ET AL., supra note 38 , at 16.

88. FED. FIN. INST. EXAMINATION COUNCIL, supra note 84.

89. The Gramm-Leach-Bliley Act, ELECTRONIC PRIVACY INFO. CTR,, http://epic.org /privacy/glba/ [http://perma.cc/2MFP-FH7K]. GLBA's privacy clauses were also heavily influenced by a wider trend of data security both in the United States and abroad. Id. 


\section{Conflicts of Interests and Attempts to Address the Legislative Gap}

This Part focuses on the problems that arise from conflicts of interest, specifically in connection with proprietary trading. Examining these issues, and various attempts at reform, coupled with the empirical data discussed in Part III, highlights why the Volcker Rule must be vigorously enforced.

There have been a few attempts to address conflicts of interests inherent in proprietary trading within banks. But as will be demonstrated empirically in Part III below, these attempts have not been successful. One mechanism, denoted as "Chinese Walls," has been defined as "a self-styled regulatory mechanism aimed at stemming the flow of material information from one department in a conglomerate to another and resolving the legal problems associated with conflicts of interest and duty generally. $" 90$ Our empirical results demonstrate, however, that proprietary trading still gives rise to conflicts of interest even if Chinese Walls are effective in limiting access to information between departments. The second mechanism, inherent in the Volcker Rule, is a much more important mechanism given its potential to severely curtail conflicted trades and, as argued below, needs to be enforced rather than eliminated.

\section{A. The Conflict: Proprietary Trading}

\section{Different Viewpoints on Bank Conflicts of Interest and Proprietary} Trading

There are varying viewpoints in this context about the nature of the harm presented by conflicts of interest inherent in proprietary trading. Some commentators view proprietary trading and conflicts of interest as harmful on multiple levels. For example, Senators Jeff Merkley and Carl Levin blamed unchecked conflicts of interest (deregulation of banking entities) and proprietary trading for financial crashes during the Great Depression as well as in 2008, noting that "poor policy choices and lax regulation led to unbridled proprietary trading and unchecked conflicts of interest that helped create the conditions that resulted in the crisis." ${ }^{.91}$ This resulted in dire consequences, the senators noted, because although "a massive economic collapse was prevented, the subsequent recession was nonetheless extraordinarily severe, and the recovery has been slow."92

On the other hand, some scholars are more skeptical about attempts to eradicate conflicts of interest in the banking sector, particularly when it comes

90. Harry MCVEa, Financial Conglomerates AND THE Chinese Wall: REGULATING CONFLICTS OF INTEREST 8 (1993).

91. Id. at 516,553

92. Id. at 515 . 
to proprietary trading. Julius Loeser contends that while proprietary trading happens, it is not a problem - for a couple of reasons. ${ }^{93}$ For one, he contends that proprietary trading occurs on such a small scale that its effect is essentially null"[p]roprietary trading at traditional large banks, such as Wells Fargo and Bank of America, accounts for less than one percent of total revenue." $" 94 \mathrm{He}$ further claims that, instead of helping fix problems, attempting to limit proprietary trading via the Volcker Rule "could hurt healthy diversification of income streams of banking organizations and reduce capital flows to small and medium-sized businesses, neither of which is a positive pro-safety and soundness, financial growth-oriented economic outcome." 95

Taking an approach more in the middle, Professor Manasfi worries that banning all proprietary trading is the wrong course of action to take, claiming that it brings some benefits. ${ }^{96}$ Rather than arguing that proprietary trading has no negative effects, however, Professor Manasfi contends that "we must look at some of the more nuanced causes of the financial crisis and not just throw the baby, the potential benefits of deregulation, out with the bathwater, excessive risk taking." 97 Her argument focuses on systemic risk, and acknowledges that conflicts of interest may raise different concerns: "[ $t]$ he most egregious conflict of interest examples include designing products to fail, selling them to clients and then making trading bets on the products' collapse." 98 That said, she believes that conflicts of interest can be addressed through some means other than the Volcker Rule, such as through requiring more disclosures. ${ }^{99}$

\section{Problems Associated with Proprietary Trading}

When the Glass-Steagall Act was repealed in full after the passage of the Financial Services Modernization Act of 1999, previous restrictions on proprietary trading ("allow[ing] commercial banking groups to invest and trade in securities for their own accounts") were removed, enabling banks to re-engage in this sort of behavior. ${ }^{100}$ In other words, a practice creating very serious conflicts of interest was suddenly allowed. 101 "Proprietary trading offers

93. Julius L. Loeser, The "Volcker Rule": Barring Banking Organizations from Proprietary Trading, Fund Investment, and Sponsorship, 11 ENGAGE 45, 48 (2010).

94. Id.

95. Id.

96. Julie A.D. Manasfi, Systemic Risk and Dodd-Frank's Volcker Rule, 4 WM. \& MARY BUS. L. REV. 181, 208 (2013).

97. Id.

98. Id. at 211 .

99. Id. at 212 .

100. Jeff Merkley \& Carl Levin, The Dodd-Frank Act Restrictions on Proprietary Trading and Conflicts of Interest: New Tools To Address Evolving Threats, 48 HARV. J. ON LEGIS. 515 , 519 (2011).

101. Id. 
financial firms with clients the additional temptation to magnify returns by taking advantage of their knowledge of investment activities of their clients."102 Furthermore, Senators Merkley and Levin noted:

Two notable ways in which banks put their proprietary trading interests ahead of their clients were (1) the creation and marketing of products to clients that were secretly designed to fail; and (2) the use of client trading information against the interests of those clients and others in the markets. ${ }^{103}$

Ultimately, the problem comes down to the following. A bank is using assets of the people it is supposed to be serving as clients for its own economic gain. ${ }^{104}$ Furthermore, as Senator Merkley pointed out, what happened was not just morally questionable-_it had real implications for banks' clients:

The rise of securitization tempted firms to engage in an egregious form of selfdealing: designing products to fail, selling them to unsuspecting clients, and making proprietary trading bets on the products' collapse. This practice has been analogized to a firm designing a car with faulty brakes and then purchasing a life insurance policy on the driver. ${ }^{105}$

Essentially, banks loaded the dice so that they could profit from the short side of a transaction, while leaving clients to deal with the long term as products declined in value. ${ }^{106}$ Additionally, there could be more long-term harm to clients when banks use clients' information against clients during their future trades. ${ }^{107}$

Commentators have discussed the connection between the Volcker Rule's prohibitions on proprietary trading and incentives for firms to use non-public client information, and others have considered utilizing the Volcker Rule as a means to reduce use of non-public client information. Professor Tuch contends that 'the rule's prohibition on proprietary trading will significantly reduce opportunities and incentives for financial conglomerates to use non-public client information in violation of information barriers, especially considering that proprietary trading was a key driver of financial conglomerates' revenues." "108 Senators Jeff Merkley and Carl Levin noted that many advocates of the Volcker Rule, including themselves and other senators, saw potential in the rule's ability to address concerns relating to conflicts of interest and proprietary trading. ${ }^{109}$

\begin{aligned} & \hline 102.$I d$. at 522. \\ & 103.$I d$. at 523. \\ & 104.$I d \\ & 105. I d \\ & 106$. See id. (outlining what one bank did in proprietary trading and how this was \\ & 107. Id. \\ & 108. Andrew F. Tuch, Financial Conglomerates and Information Barriers, 39 J. CORP. \\ & harmful to the bank's clients). \\ & L. 563, $567(2014)$. Merkley \& Levin, supra note 100, at $531-37\end{aligned}$.


Thus, while the idea that the Volcker Rule could be used to discourage trading on proprietary, non-public information is certainly not new, this Article seeks to provide important empirical support for this claim.

\section{B. Chinese Walls}

Chinese Walls have been applauded as being instrumental in preventing conflicts of interest by separating confidential non-public information of banking clients from that of traders. ${ }^{110}$ One scholar contended that they are "analogous to corporate codes of conduct and offer insight about how a code of conduct should function and what legal standards should govern when the government or a private party seeks to impose vicarious liability on a public company." "I11 In the banking context, Chinese Walls are rarely, in practice, shown to be shields against liability. ${ }^{112}$

Following the prosecution of a litany of insider trading cases, ${ }^{113}$ Congress passed the Insider Trading and Securities Fraud Enforcement Act of 1988 (ITSFEA). ${ }^{114}$ This Act set forth the following requirements:

Every registered broker or dealer shall establish, maintain, and enforce written policies and procedures reasonably designed, taking into consideration the nature of such broker's or dealer's business, to prevent the misuse in violation of this chapter, or the rules or regulations thereunder, of material, nonpublic information by such broker or dealer or any person associated with such broker or dealer. ${ }^{115}$

Section 204 of the Investment Advisers Act contains a similar requirement for investment advisers. ${ }^{116}$

In the wake of the Enron and WorldCom scandals of the early 2000s, Congress adopted the Sarbanes-Oxley Act (SOX). ${ }^{117}$ Pursuant to SOX, Section $15 \mathrm{D}(\mathrm{a})(3)$ was added to the 1934 Act. ${ }^{118}$ Relevant to our analysis, this section requires that the SEC or self-regulatory organizations (SROs), such as National Association of Securities Dealers (NASD), promulgate rules to "establish

110. See, e.g., Harry McVea, Financial Conglomerates and Conflicts of Interest: Resolving a Regulatory Dilemma, 47 N. IR. LEGAL Q. 239, 243-44 (1996) (describing Chinese Walls as the "linchpin of the financial conglomerate regulatory system").

111. Harvey L. Pitt \& Karl A. Groskaufmanis, Minimizing Corporate Civil and Criminal Liability: A Second Look at Corporate Codes of Conduct, 78 GEO. L.J. 1559, 1606 (1990).

112. Id. at 1624.

113. See RalPH C. FERrara ET AL., FERRARA ON INSIDER TRAding \& THE WALl $\S$ $9.03(2017)$

114. Pub. L. No. 100-704, codified in a number of provisions of the federal securities laws.

115. 15 U.S.C. $\$ 78 \mathrm{o}(\mathrm{g})(2018)$. Note that this provision was originally Section $15(\mathrm{f})$ of the Securities Exchange Act.

116. Id. $\S 80 \mathrm{~b}-4 \mathrm{a}$.

117. Pub. L. No. 107-204, 116 Stat. 745 (July 30, 2002) (codified at 15 U.S.C. $§ 78$ ).

118. S. REP. NO. 107-205 (2002). 
structural and institutional safeguards within registered brokers or dealers to assure that securities analysts are separated by appropriate informational partitions within the firm from the review, pressure or oversight of those whose involvement in investment banking activities might potentially bias their judgment or supervision." 119 The NASD and New York Securities Exchange (NYSE) drafted rules that were approved by the SEC.

A Chinese Wall is not foolproof. Professor Tuch argued that it is difficult to prove that a firm failed to maintain a Chinese Wall, or that it breached its Wall. ${ }^{120}$ Furthermore, "[d] etection may be getting even harder as trading speeds and volumes have increased." 121 One of us, Professor Seyhun, previously remarked that "Chinese Walls are porous and ineffective, and material, nonpublic information about the client firm is allowed to pass between departments of the securities firms." "122 Accordingly, Professor Seyhun argues that firms should assume from the start that Chinese Walls are porous and that additional safeguards need to be put in place. ${ }^{123}$ This follows from the work of Carlos E. Mèndez-Peñate, who noted that high-ranking executives, in particular, must be allowed to cross the firm's Chinese Walls to perform their corporate duties. ${ }^{124}$ Furthermore, Martin Lipton and Robert Mazur have pointed out that " $[\mathrm{t}]$ he difficulty of discovering misuse of inside information is, of course, the greatest shortcoming of the Chinese Wall approach."125

In addition, it is extraordinarily difficult to prove intentional misconduct when an alternate explanation may be offered. As Tuch notes:

In particular, suspicious trading may be the result of benign rationales, including coincidence or the superior trading skill or intellect of the traders involved, rather than failing information barriers. Disproving these benign explanations can be extraordinarily difficult, especially because direct evidence of information flows

119. 15 U.S.C. \$ 780-6(a)(3); see also Jill E. Fisch \& Hillary A. Sale, The Securities Analyst as Agent: Rethinking the Regulation of Analysts, 88 IoWA L. REV. 1035, 1077 (2003) ("In addition, the Act mandates rulemaking to increase disclosure of analyst conflicts of interest, including the extent of an analyst's investments in securities of a covered issuer; business relationships between covered issuers and brokerage firms; compensation received from the issuer by the analyst or the brokerage firm; and any other material conflicts."); S. J. Hilgers, Under the Influence: Analyzing Wall Street Research Analyst Conflicts of Interest and the Responses Designed To Induce Impartiality, 31 SEC. REG. L.J. 427, 451 (2003).

120. Tuch, supra note 108, at 589.

121. Id. at 589 (citing Insider Trading: Tipping the Scales, ECONOMIST (Oct. 15, 2011), http://www.economist.com/node/21532280 [http://perma.cc/33AW-ULKB]).

122. Seyhun, supra note 13 , at 371 .

123. Id. at 387 .

124. See Carlos E. Mèndez-Peñate, The Bank "Chinese Wall": Resolving and Contending with the Conflicts of Duties, 93 BANKING L.J. 674, 685 (1976) (discussing potential problems associated with maintaining Chinese Walls).

125. Martin Lipton \& Robert B, Mazur, The Chinese Wall Solution to the Conflict Problems of Securities Firms, 50 N.Y.U. L. REV. 459, 494 (1975). 
is seldom available, and regulators must therefore rely on circumstantial evidence to prove wrongdoing. ${ }^{126}$

Furthermore, "[g]iven that the Wall is largely dependent upon selfenforcement in an arena where self-interest is so prevalent it would seem unrealistic to assume at all times and in all circumstances that the Wall will be completely effective." 127

Professor Tuch has reviewed empirical studies suggesting that the notion that Chinese Walls are effective in separating information flow within a firm is misplaced. ${ }^{128}$ For example, he cites a study by Professor Bodnaruk and colleagues that finds that the retail branches of investment banks often took positions in firms that were targets of acquisitions after negotiations had started - and the investment banking (advisory) branches of said banks were already representing the targets in an advisory capacity during the targets' negotiations with potential acquirers. ${ }^{129}$ Thus, the Bodnaruk study concludes that the investment banks were likely trading on privileged, private information gathered by the advisory branch in its retail operations. ${ }^{130}$ In addition, Professor Tuch notes that Chinese Walls have not only been ineffective in preventing trades on improperly leaked information, they have also failed to prevent firms from bowing to conflicts of interest and violating the duties owed to clients, ${ }^{131}$ particularly in the mergers-and-acquisitions context. ${ }^{132}$

\section{The Volcker Rule}

In response to the 2008 financial crisis, the U.S. enacted legislation attempting to address the perceived problems of the financial industry, entitled the Dodd-Frank Wall Street Reform and Consumer Protection Act of 2010 (the

126. Tuch, supra note 108, at 589 (citing Melissa Maleske, An Insider Falls, INSIDE Counsel 28-29 (Aug. 2012); Chad Bray et al., Insider Case Lands Big Catch, WALL ST. J. (June 15, 2012, 7:55 PM), http://www.wsj.com/articles/SB10001424052702303822204577468470878668722 [http://perma.cc/4646-B42Z]).

127. MCVEA, supra note 90, at 214; see also Norman S. Poser, Conflicts of Interest Within Securities Firms, 16 BROOK. J. INT'L L. 111, 114 (1990) [hereinafter Poser, Conflicts] (stating that Chinese Walls are a "fake" (quoting Improper Activities in the Securities Industry: Hearings before the Senate Comm. on Banking, Housing, and Urban Affairs, 100th Cong., 1st Sess. 89 (1987) (statement of Sen. William Proxmire))).

128. Tuch, supra note 108 , at 585-86. In addition, Tuch calculates "various trading returns for a given financial conglomerate in a particular period and then compar[es] those retums" in his discussion of failure of information barriers and the Volcker Rule's influence on those barriers.

129. Id. at 586 \& n.118 (citing Andriy Bodnaruk et al., Investment Banks as Insiders and the Market for Corporate Control, 22 REV. FIN. STUD. 4989, 5020-24 (2009)).

130. Bodnaruk, supra note 129 , at 5024 .

131. Tuch, supra note 108 , at $572-74$.

132. See id. at 776 (discussing how firms may try to get around the problems here, noting that "in their contracts with clients in various contexts, such as mergers and acquisitions and securities underwriting, financial conglomerates routinely disclaim the existence of agency relationships and fiduciary duties"). 
"Dodd-Frank Act"). ${ }^{133}$ Sections 619 and 621 of the Act specifically limit conflicted trades ${ }^{134}$ _and are collectively referred to as the Volcker Rule. ${ }^{135}$ The stated purpose of the Rule is:

(1) to reduce risks to the financial system by limiting the ability of banks to engage in activities other than socially valuable core banking activities; (2) to protect taxpayers and reduce moral hazard by removing explicit and implicit government guarantees for high-risk activities outside of the core business of banking; and

(3) to eliminate any conflict of interest that arises from banks engaging in activities from which their profits are earned at the expense of their customers or clients. ${ }^{136}$

The Volcker Rule was implemented to promote financial stability in the United States by "improving accountability and transparency in the financial system ... to protect the American taxpayer by ending bailouts, [and] to protect consumers from abusive financial services practices." 137 The Rule has historical precedent in the Glass-Steagall Act of 1933. When Paul Volcker, former Federal Reserve Chairman, proposed the Rule, his central idea was to shield the banking system from non-banking capital market risks, and thus take control of volatility of bank earnings and threats to financial stability. ${ }^{138}$

The Rule was intended to prohibit bank holding companies and subsidiaries with access to the discount window at the Federal Reserve or to FDIC insurance from engaging in high-risk activities such as proprietary trading, speculative

133. Dodd-Frank Wall Street Reform and Consumer Protection Act, Pub. L. No. 111203, 124 Stat. 1376-2223 (2010) (codified as amended in scattered sections of 12 and 15 U.S.C). For a history of the Volcker Rule, see Julie A.D. Manasfi, Dodd-Frank's Volcker Rule Revisited: Do the Potential Costs Outweigh the Purported Benefits?, BANKIng \& FIN. SERVS. POL'Y REP. 12, 16 (May 2017).

134. 12 U.S.C. $\$ 1851(2018) ; 15$ U.S.C. $\$ 77 \mathrm{a}(2018)$.

135. See Ryan K. Brissette, The Dodd-Frank Wall Street Reform and Consumer Protection Act: The Volcker Rule's Unintended Consequences, 15 N.C. BANKING INST. 231, 239-40 (2011) (identifying the above-mentioned sections as the "Volcker Rule").

136. 21st Century Glass-Steagall Act of 2017, H.R. 2585, 115th Cong. (2017). According to one commentator:

The Rule's primary purpose is to be a small piece of the Dodd-Frank Wall Street Reform and Consumer Protection Act of 2010 (Dodd-Frank), aimed at alleviating the need to bail out large banking entities that pose systemic risk to the financial health of the United States. It does so by limiting the amount of speculative, highrisk investments at banking entities. Instead, it encourages banking entities to focus on client activities that are generally lower-risk.

Brissette, supra note 135 , at 237.

137. Dodd-Frank Wall Street Reform and Consumer Protection Act $\$ 619$.

138. Jussi Keppo \& Josef Korte, Risk Targeting and Policy Illusions-Evidence from the Announcement of the Volcker Rule, MGMT. SCI. (Nov. 17, 2016), http://doi.org/10.1287 /mnsc.2016.2583 [http://perma.cc/NK5B-WBCV]. 
hedge fund, and private equity investment. ${ }^{139}$ The trading prohibition applies to short-term trading. The prohibition comes with limited exceptions, allowing proprietary trading pertinent to the following activities: underwriting, marketmaking, risk-mitigating hedging, trading in domestic government debt, trading on behalf of customers, and trading by insurance companies. ${ }^{140}$

All U.S.-organized banking entities, including their worldwide subsidiaries, and all the U.S.-located subsidiaries of foreign-organized banking entities are subject to the Rule. ${ }^{141}$ The Rule effectively prohibits U.S. banks and foreign banks with U.S. subsidiaries from engaging in proprietary trading and restricts their private equity activity. ${ }^{142}$ In order to comply with these regulations, banking entities subject to the Rule must expend significant resources to ensure that they take actions in four important areas: compliance and reporting standards; data gathering and reporting structures; compensation and governance; and communication and culture. ${ }^{143}$ The deadline for banks to comply with the Rule underwent several extensions, and the Rule came into effect on July 21,2015 . $^{144}$

The following sections cover the important provisions of the Volcker Rule that aim to address conflicts of interest. Section 619 generally prohibits universal banks from proprietary trading, thus inhibiting associated conflicts of interest, except in a limited number of securities and situations including trading in government obligations and market-making; however, even permitted activities and transactions are subject to prohibition if they "would involve or result in a material conflict of interest . . . between the banking entity and its clients . . .."145 Section 621 essentially prevents banks from executing any transaction within one year after the date of the first closing of the sale of an asset-backed security that would involve a material conflict of interest with any investor. ${ }^{146}$

The ban attempts to remove the conflict of the crisis described above by removing one of the principals in the transaction, the proprietary trading desk. In

139. Jack Bao, Maureen O'Hara \& Alex Zhou, The Volcker Rule and Market-Making in Times of Stress 29 (Finance and Economics Discussion Series 2016-102 Working Paper, 2016), http:// www.federalreserve.gov/econresdata/feds/2016/files/2016102pap.pdf [http://perma.cc/HRH6-KTMH].

140. Vinita Tandon, The Volcker Rule: Clarifying the Anti-Evasion Provision to Facilitate Compliance, 20 N.C. BANKING INST. 385 (2016).

141. Volcker Rule, DAVIS POLK 3-4 (Jan. 6, 2014), http://www.davispolk.com/doddfrank/memoranda/volcker-rule [http://perma.cc/5W8Z-U6UQ].

142. Volcker Rule, BD. GOVERNORS FED. RESERVE SYS., $\mathrm{http}: / /$ www.federalreserve.gov/supervisionreg/volcker-rule.htm [http://perma.cc/9GMP-SYX5].

143. Steve Culp, Final Volcker Rule Leaves Banks Facing Compliance Hurdles, FORBES (Dec. 17, 2013), http://www.forbes.com/sites/steveculp/2013/12/17/final-volcker-rule-leavesbanks-facing-compliance-hurdles [http://perma.cc/XND8-98ZX].

144. Daniel Roberts, Volcker Rule Takes Effect Today After Years of Delay, FORTUNE (July 22, 2015), http://fortune.com/2015/07/22/volcker-rule [http://perma.cc/Y7F5-DSAY].

145. 12 U.S.C. $\S 1851$ (2018).

146. Under Rule 127B, a material conflict of interest is found to be material under a two-prong test. 
doing so, the bank no longer faces the threat of being divided between itself over its customers - or in actuality, being loyal to itself over its customers. According to one scholar, "[t]he Volcker Rule, in effect, was motivated by a desire to return to a traditional banking model-to create a regulatory divide, much like the Glass-Steagall Act before its repeal in 1999 ...".147 According to Senators Merkley and Levin, it was necessary "(1) to separate federal support for the banking system from speculative trading activity with the banking entity's own capital; (2) to reduce potential conflicts of interest between a banking entity and its customers; and (3) to reduce risk to banking entities and nonbanking financial companies designated for supervision by the Federal Reserve Board."148

The former Federal Reserve Chairman said:

When the bank ... is trading for its own account, it will almost inevitably find itself consciously or inadvertently, acting at cross purposes to the interests of an unrelated commercial customer of a bank .... [E]ven with best efforts of board and management, so-called Chinese Walls can [not] remain impermeable against the pressures to seek maximum profit and personal remuneration. ${ }^{149}$

Section 620 of the Act directs regulators to consider whether any other banking activities should be restricted in order to protect the safety and soundness of the financial system. ${ }^{150}$ But Congress did allow for some exceptions. If a statutorily permitted activity of Section 619 is found to pose a material conflict of interest, the bank may continue with it if:

(1) the entity makes clear, timely and effective disclosure and in a manner that that provides the client an opportunity to negate any adverse effect created by the conflict; or

(2) the entity has information barriers that prevent the conflict of interest from involving or resulting in a materially adverse effect on a client. However, an entity cannot rely an information barrier if it knows or reasonably should have known that even with the barrier, a materially adverse effect may result and in that case,

147. Charles K. Whitehead, The Volcker Rule and Evolving Financial Markets, 1 HARV, BUS. L. REV. 39, 42-43, 66 (2011); see also Andrew F. Tuch, Conflicted Gatekeepers: The Volcker Rule and Goldman Sachs, 7 VA. L. \& BUS. REV. 365 (2012) (discussing both traditional and new justifications for regulating conflicts of interest). 2011). 148. Am. Bankr. Inst,, Legislative Highlights, AM. BANKR. INST. J. 8, 82 (Aug. 30 ,

149. Paul Volcker's Prepared Testimony to Senate Bank Panel, REUTERS (Feb. 2, 2010), http://www.reuters.com/article/us-financial-regulation-volcker-text/paul-volckers-preparedtestimony-to-senate-bank-panel-idUSTRE6115WK20100202 [http://perma cc/D43N-BX6G].

150. Dodd-Frank Wall Street Reform and Consumer Protection Act, Pub. L. No. 111203, $\S 629,124$ Stat. 1376-2223 (2010) (codified as amended in scattered sections of 12 and 15 U.S.C.). 
timely and effective disclosure of the conflict would be required to "cleanse" the conflict. $^{151}$

That said, the Volcker Rule has faced some criticism and opposition. It has been critiqued for being over-simplified in its proscription. Banks will find alternative routes to arbitrage the Rule and execute the same trades, ${ }^{152}$ and, " $[t]$ his new round of financial engineering ... may further increase the level of unnecessary complexity in the financial markets and thus make effective regulation even more difficult to achieve."153 Some critics have attempted to show, with empirical data, that "the Volcker Rule has a deleterious effect on corporate bond liquidity and dealers subject to the Rule become less willing to provide liquidity during stress times. ${ }^{154}$

Foreign-organized banking entities have been especially critical of the Rule because of its extraterritorial effects on foreign financial institutions. For example, Erkii Liikanen, Chairman of the European Union's High Level Expert Group on Banking Reform, criticized the Rule for being too narrow because it targets almost exclusively proprietary trading and uses an approach much too radical to address the problem. ${ }^{155}$ As of December 2013, fifteen German banks were affected, including Deutsche Bank, Commerzbank, and UniCredit. ${ }^{156}$ The Rule imposes substantial compliance costs on both Deutsche Bank and Commerzbank to satisfy its robust and complicated compliance measures.

In addition, the Rule imposes significant reporting and recordkeeping requirements when bank entities engage in prohibited proprietary trading. In order to meet the reporting requirement, the Rule compels bank entities to initiate programs designed to prohibit future violations of the Rule; to ensure the programs' operation, it requires periodic review by senior management and certification from the CEO of the bank. ${ }^{157}$

151. Id.

152. "Banking activities may still be affected by proprietary trading- an end-run around the Volcker Rules' divide- but now through the banks' reliance on risk out-sourcing to hedge funds and the hedge fund industry." Whitehead, supra note 147, at 70. Letter from David Arkuch \& Bartlett Naylor, Pub. Citizen, to Secy. Tim Geithner et al. Re: Prohibitions on Proprietary Trading and Certain Interests in, and Relationships with, Hedge Funds and Private Equity Funds, at 44 (Feb. 13, 2012), http://www.sec.gov/comments/s7-41-11/s74111-296.pdf [http://perma.cc/ 8UBT-KBPE].

153. Saule T. Omarova, The Dodd-Frank Act: A New Deal for a New Age, 15 N.C. BANKING INST. 84, 93 (2011).

154. Bao et al., supra note 139 , at 29.

155. Chair of E.U. Expert Group Calls Volcker Rule the Most Narrow and Radical Approach, 7 HEDGE FUNDS \& PRIV. EQUITY 3 (CCH).

156. Christine P. Henry, The Volcker Rule and the Presumption Against Extraterritoriality: Utterly Incompatible, 7 WM. \& MARY BUS. L. REV. 825, 834-35 (2016).

157. See, e.g., 12 C.F.R. $\$ 351.20$ (2017) (listing specifications on reporting requirements under the Volcker Rule). 
Despite these criticisms, however, we join in with other scholars who advocate enforcement of the Volcker Rule. ${ }^{158}$ We provide new empirical evidence in support of this proposition. The next Part details our empirical evidence from which we conclude that the conflicted trades that the Volcker Rule, particularly sections 619 and 621 , is designed to proscribe are alive and well. Based on our empirical study, we urge regulators to improve the enforcement mechanisms of the Rule.

\section{III.The Empirical Evidence of the Continuing Problem of Conflicts of Interest}

In this Section, we empirically investigate the nature and profitability of trading by banks and other insiders. Banks typically acquire insider trading status on a temporary basis when they are hired as investment advisers. ${ }^{159}$ As a result, they become subject to insider trading reporting requirements and trading restrictions. ${ }^{160} \mathrm{We}$ expect the temporary insider status to provide banks and other investment advisers with valuable, material non-public information. ${ }^{161}$ Furthermore, we expect the temporary insiders to obtain and trade on adverse information about their clients. ${ }^{162}$ Profitable trading by banks and other investment advisers using adverse information about the clients can create conflicts of interest because such trading will publicize the adverse information prematurely, depress stock price of the client firms, and make it more difficult for the client firms to solve their financial problems, which they hired the banks and investment advisers to help solve in the first place. ${ }^{163}$ Under these conditions, we expect that strict enforcement of the Volcker Rule would reduce these systemic risks and potential conflicts of interest.

To test our hypothesis, we obtained stock price information from the Center for Research in Security Prices (CRSP). The insider trading data comes from the

158. See supra notes 108-109; see also Rafael E. Gonzalez Ramos, The Good, the Bad, and the Volcker Rule?, 3 U.P.R. BUS. L.J. 124, 134 (2012) ("The Volcker Rule is a good approach to protect the United States financial market and taxpayers, as well as international financial markets and taxpayers"); Onnig H. Dombalagian, The Expressive Synergies of the Volcker Rule, 54 B.C. L. REV. 469 , 533 (2013) ("An expressive implementation of the Rule's market making exemption not only will help to differentiate the prospective roles of bank-affiliated dealers, nonbank financial companies, and end-users of financial instruments . . . but also may improve the long-term vitality and competitiveness of financial markets"); Douglas M. Branson, A Return to Old-Time Religion? The Glass-Steagall Act, the Volcker Rule, Limits on Proprietary Trading, and Sustainability, 11 U. ST. THOMAS L.J. 359, 381 (2014) (expressing concern that the Volcker Rule does not go far enough).

159. See Dirks v. SEC, 463 U.S. 646 (1983) (discussing the concept of temporary insider).

Volcker rule).

160. See 12 C.F.R. $\$ 351.20$ (for information on reporting requirements under the

161. See Section II(C) (highlighting certain aspects of the Volcker rule).

162. See, e.g., McDonnell, supra note 6 (discussing an example of accumulation of adverse information).

163. See Section II(A) (discussing conflicts of interest in proprietary trading and resulting harms). 
union of the Thomson Reuters Insider Filing Data Feed (1996 to 2016) and backward extensions using archived annual purchases from the National Archives (1975 to 1995) (collectively, "Insider Trading Database"). Our sample includes U.S. common stocks (CRSP share codes of 10 or 11) that are covered by all three databases. The time period is from January 1975 through December 2016. We restrict attention to this interval due to the availability of insider trading data, which first became available in January 1975. We include observations beginning only from the time when the firms first appear in the combined Insider Trading Database. We adjust stock returns for delisting using the CRSP delisting file. ${ }^{164}$ Our final dataset has over 20,000 unique CUSIPs and over $3,500,000$ observations.

The combined Insider Trading Database includes all trades reported to the SEC-Ownership Reporting System. The data contains all open market purchases and sales by officers and directors, executives, and investment advisers of publicly traded firms. Top executives are limited to officer and director (OD), officer, director, and beneficial owner $(\mathrm{H})$, chairman of the board $(\mathrm{CB}), \mathrm{CEO}$, $\mathrm{CFO}$, controlling person (CP), general partner (GP), and president (P). Investment bankers are coded with "IA." Officers are defined as all other officers. Large shareholders with an officer title are included in the sample. Outside large shareholders ( $\mathrm{SH}$ ) and outside beneficial owner of more than $10 \%$ of a class security (B) are excluded.

Shares acquired through the exercise of options, stock awards, and trades with corporations are excluded. The final sample is limited to firms for which stock return data are available in CRSP. Finally, in order to deal with potential misreports and incorrect outliers, three filters are used. On the insider transaction date, (1) the insider transaction price must be less than twice the closing price of the stock, (2) the number of shares of the insider transactions will be less than the daily volume of trade of the stock, and (3) the number of shares of the insider transaction will be less than the outstanding number of shares for the stock. ${ }^{165}$

We measure the profitability of insider trades starting from the insider trade date. We measure abnormal stock return behavior using the cumulative marketadjusted abnormal daily stock returns (CAR) starting from the trade date (date 0 ) for a period of $T$ days:

$$
C A R_{i, T}=\sum_{t=0}^{T} \dot{H}_{i, t}\left(r_{i, t}-r_{m . t}\right) \text {, }
$$

where $H_{i, t}$ takes the value 1 for insider purchases and -1 for insider sales. Thus, we define an insider purchase to be abnormally profitable if the stock price outperforms the general stock market after the purchase. Similarly, we define an

164. We follow the procedure used in Tyler Shumway, The Delisting Bias in CRSP Data, 52 J. FIN. 327 (1997).

165. Qualitative results do not change if these filters are not enforced. Results are available from the authors upon request. 
insider sale to be abnormally profitable if the stock price underperforms the general stock market after the sale. The variable $r_{i, t}$ is the with-dividend return to stock $i$ for day $t$, and $r_{m, t}$ is the with-dividend return to the CRSP equallyweighted portfolio of all New York Stock Exchange, American Stock Exchange, and NASDAQ stocks for day $t$. We examine the profitability of insider trades for $\mathrm{T}=10,20,50,100,150,200$, and 250 days following insiders' transactions.

To focus on insider transactions that are likely to be based on material, nonpublic information, we first require that the abnormal profitability (CAR) of insiders' transactions exceed $5 \%$ by day 10,20,50,100,150,200, and 250 . Summary statistics of the data for the period 1975-2016 are shown in Table 1. This table provides summary statistics of insider trades by officers, top executives, and investment bankers. Panel A provides number of trades, average number of shares purchased, and average number of shares sold by officers, executives and investment advisers in NYSE, AMEX, and NASDAQ. The preSOX period includes the time frame of January 1, 1975 to August 31, 2002 and the post-SOX period includes the time frame of September 1, 2002 to December $31,2016$. 
Table 1: Summary Statistics of Insider Trades for the 1975-2016 Period Panel A: Number of Insiders' Trades

\begin{tabular}{|c|c|c|c|}
\hline & $\begin{array}{l}\text { Number of } \\
\text { Purchases }\end{array}$ & $\begin{array}{c}\text { Number of } \\
\text { Sales }\end{array}$ & $\begin{array}{l}\text { Number of Total } \\
\text { Transactions }\end{array}$ \\
\hline \multicolumn{4}{|l|}{ Pre-SOX } \\
\hline Officers & 462,394 & 707,381 & $1,169,775$ \\
\hline $\begin{array}{l}\text { Executives } \\
\text { Investment }\end{array}$ & 160,882 & 285,133 & 446,015 \\
\hline Bankers & 323 & 283 & 606 \\
\hline \multicolumn{4}{|l|}{ Post-SOX } \\
\hline Officers & 197,923 & $1,102,325$ & $1,300,248$ \\
\hline $\begin{array}{l}\text { Executives } \\
\text { Investment }\end{array}$ & 104,512 & 744,529 & 849,041 \\
\hline Bankers & 628 & 336 & 964 \\
\hline Total & 926,662 & $2,839,987$ & $3,766,649$ \\
\hline
\end{tabular}

Panel B: Insiders' Trades by Insider Relationship

\begin{tabular}{|lccc|}
\hline & $\begin{array}{c}\text { Average } \\
\text { Number of } \\
\text { Shares } \\
\text { Purchased }\end{array}$ & $\begin{array}{c}\text { Average } \\
\text { Number of } \\
\text { Shares Sold }\end{array}$ & $\begin{array}{c}\text { Total Shares } \\
\text { Purchased- Sold } \\
\text { (Millions) }\end{array}$ \\
\hline \hline Pre-SOX & & & \\
Officers & $3,694.66$ & $8,790.65$ & $4,321.92-10,283.08$ \\
Top Executives & $3,913.58$ & $13,039.08$ & $1,745.52-5,815.63$ \\
Investment Bankers & $6,096.60$ & $6,355.66$ & $3.69-3.85$ \\
Post-SOX & & & \\
Officers & $4,179.65$ & $12,764.91$ & $5,434.58-16,597.55$ \\
Top Executives & $1,904.37$ & $8,052.33$ & $1,616.89-6,836.76$ \\
Investment Bankers & $1,908.28$ & $13,277.45$ & $1.84-12.80$ \\
Total & & & $13,124.44-39,549.67$ \\
\hline
\end{tabular}


Table 1 further displays the number of trades, average number of shares purchased, and average number of shares sold by relationship. This table provides information about insider trades for all three insider groups. We also separate the analysis period as pre-SOX and post-SOX. The pre-SOX period includes the time frame of January 1, 1975 to August 31, 2002 and the post-SOX period includes the time frame of September 1, 2002 to December 31, 2016. The number of trades in the post-SOX era is somewhat higher than the number of trades in the pre-SOX era for all three groups of insiders, even though the preSOX period contains more than 27 years of data while the post-SOX period contains about 13 years of data.

Our database is quite large, containing about 3.7 million insider trades from 1975 to 2016 . The total number of shares sold is about 40 billion while the total number of shares purchased is about 13 billion over this time period. Insiders on average tend to sell more shares than they purchase because they receive a significant number of shares as part of executive compensation.

Tables $2,3,4$, and 5 provide the average abnormal market-adjusted returns (CAR) of insider trades in 10,20,50,100,150,200, and 250-day horizons. The market-adjusted abnormal return for each trade is computed as,

$$
C A R_{i, T}=\sum_{t=0}^{T} H_{i, t}\left(r_{i, t}-r_{m, t}\right)
$$

where $r_{i, t}$ is the with- dividend return to stock $i$ on day $t$ and $r_{m, t}$ is the withdividend return to an equally weighted portfolio of all New York Stock Exchange, American Stock Exchange, and NASDAQ stocks on day $t$. The parameter $H$ is equal to one if the insider trade is a purchase and negative one if it is a sale. The $t$-statistics are in parentheses. Estimates that are statistically significant at the $5 \%$ level or better are in bold.

Table 2 displays insiders' abnormal profits for the overall sample period for officers, top executives, investment advisers, and also for all insiders. Our database contains approximately 2.5 million transactions by officers and 1.3 million transactions by top executives. The number of transactions by investment bankers is 1,570 . 
As shown in Table 2, the abnormal market adjusted returns of all officers and top executives are positive and statistically significant for all analysis horizons. The evidence shows that all three groups of insiders, as well as the overall sample of all insiders engaged in profitable trading. Abnormal returns for officers' trades rise to more than $4 \%$, while the abnormal returns of top executives rise to more than $5 \%$ for the one-year holding period (250 trading days). For shorter holding periods, abnormal returns remain at or below one percent for the first 20 trading days (about one calendar month).

The abnormal profits of investment advisers are also positive and larger, rising to about $6 \%$ by day 20 . Moreover, these abnormal profits attain statistical significance even for short-term horizons (up to 20 days). A longer horizon analysis provides larger positive abnormal returns for the investment bankers (about $11 \%$ ), but not significantly different from zero due to the smaller sample size.

Typically, insiders tend to trade on long-lived information ${ }^{166}$ in order to avoid legal liability. Our evidence in Table 2 is consistent with this observation for officers and top executives. However, the large and immediate profitability of trading by investment banks by day ten goes against this observation. This finding suggests that the investment bankers may be less concerned about legal liability and they tend to trade on short-lived information as well.

One concern in Table 2 might be that we independently examine insiders' abnormal profits over many different horizons and some of these results that are significant at the $5 \%$ level might be due to random chance. To address this concern, we ran multiple regressions separately for officers, top executives, and investment advisers by including independent variables for non-overlapping horizons ( 1,10 days), (11,20 days), (21,50) days, (51,100 days), (101,150 days), (151,200 days), and (201,250 days). For both officers and top executives, each and every one of these non-overlapping horizons showed marginally statistically significant abnormal profits. For investment advisers, only the first 10-day investment horizon showed marginally statistically significant abnormal profits. Based on these findings, we conclude that our overall conclusions are not affected by an overlapping horizon issue.

166. Stanislav Dolgopolov, Regulating Merchants of Liquidity: Market Making from Crowded Floors to High-Frequency Trading, 18 U. PA. J. BUS. L. 651,678(2016). 


\begin{tabular}{|c|c|c|c|c|}
\hline 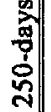 & 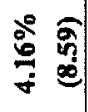 & 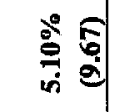 & 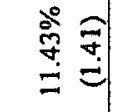 & 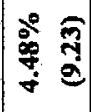 \\
\hline 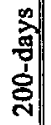 & 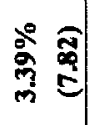 & $\begin{array}{l}0 \\
0 \\
7\end{array}$ & 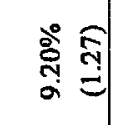 & 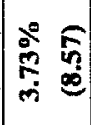 \\
\hline 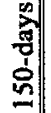 & $\stackrel{\circ}{\stackrel{8}{\circ}}$ & 过 & 今̊ํํ & $\mid \begin{array}{l}0 \\
0 \\
0 \\
0\end{array}$ \\
\hline 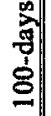 & 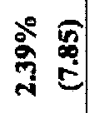 & 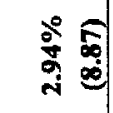 & 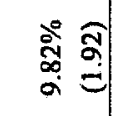 & $\mid \begin{array}{cc}20 & 0 \\
0 & 0 \\
0 & 0 \\
0 & 0\end{array}$ \\
\hline 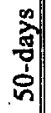 & 究 & 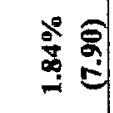 & 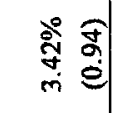 & $\mid \begin{array}{cc}0 & 9 \\
0 & 0 \\
6 & 0\end{array}$ \\
\hline 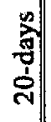 & 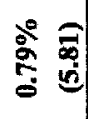 & 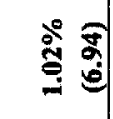 & 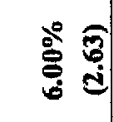 & 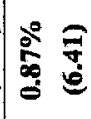 \\
\hline 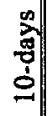 & 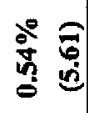 & $\begin{array}{c}\stackrel{0}{0} \\
\stackrel{0}{0} \\
\stackrel{0}{0} \\
\stackrel{0}{0}\end{array}$ & $\begin{array}{l}\stackrel{2}{a} \\
\bar{\theta} \\
\text { in }\end{array}$ & : \\
\hline 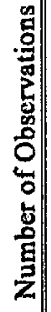 & 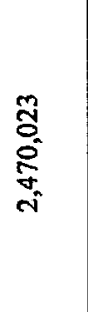 & 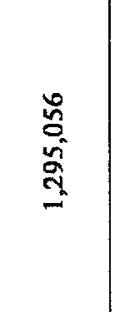 & $\stackrel{R}{n}$ & $\begin{array}{l}\frac{9}{8} \\
0 \\
8 \\
\frac{8}{2} \\
m\end{array}$ \\
\hline & 朢 & 总 & 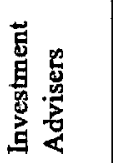 & 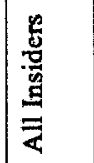 \\
\hline
\end{tabular}




\begin{tabular}{|c|c|c|c|c|c|c|}
\hline 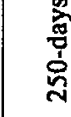 & 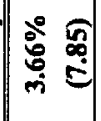 & 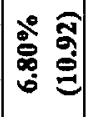 & 高 & $\mid$\begin{tabular}{l}
0 \\
0 \\
\hdashline
\end{tabular} & ذ్ & 悹 \\
\hline 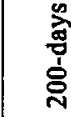 & 悹 & 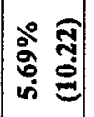 & $\frac{a}{30}$ & 总 & $\left\{\begin{array}{l}0 \\
0 \\
0 \\
0\end{array}\right.$ & 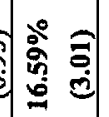 \\
\hline 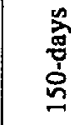 & 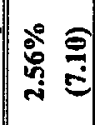 & 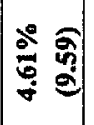 & 窇 & 商毞 & 总 & 密 \\
\hline 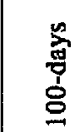 & $\frac{3}{4} \frac{2}{4}$ & 总总 & 高 & $\frac{5}{7} \Xi$ & & 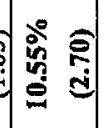 \\
\hline 害 & 产 & 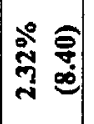 & $\mid \begin{array}{cc}0 \\
0 \\
0\end{array}$ & 容 & 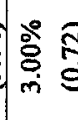 & 谱 \\
\hline 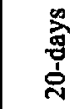 & 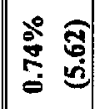 & 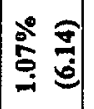 & 通哥 & 辛 & $\stackrel{\circ}{0}$ & 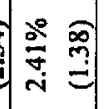 \\
\hline $\begin{array}{l}\frac{1}{2} \\
\frac{\pi}{3} \\
0 \\
0\end{array}$ & $\stackrel{8}{\circ}$ & 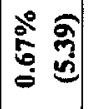 & 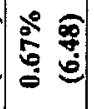 & 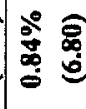 & 总 & 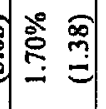 \\
\hline 㟧 & $\frac{n}{\mathbb{N}}$ & 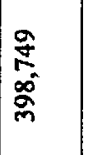 & $\begin{array}{l}\frac{9}{+} \\
\text { s. } \\
\text { s. } \\
= \\
=\end{array}$ & $\mid \begin{array}{l}0 \\
\frac{0}{m} \\
\tilde{n} \\
\tilde{n}\end{array}$ & $\stackrel{\infty}{\underset{3}{3}}$ & 겅 \\
\hline & 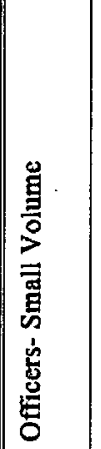 & 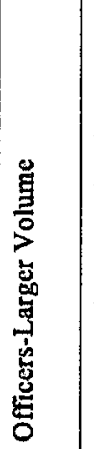 & 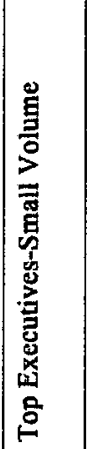 & 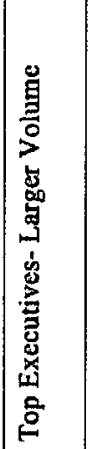 & 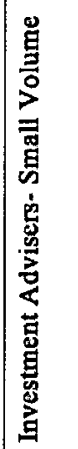 & 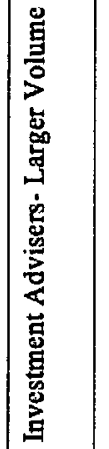 \\
\hline
\end{tabular}


We next examine the volume of trading. If insiders understand the implications of private information and do not worry about the legal consequences of their trading, we would expect them to trade greater numbers of shares when they have more valuable information. Our evidence is shown in Table 3, which displays insiders' abnormal profits for the overall period grouped by small and large volumes of trades. We define small trading volume as less than or equal to 10,000 shares; and large trading volume as more than 10,000 shares.

Our evidence is consistent with the inference that insiders understand the value of their information and they are not overly concerned about legal consequences of their trading. For officers, abnormal profits rise from $3.7 \%$ to $6.8 \%$ when insiders trade less than 10,000 shares to more than 10,000 shares. For top executives, abnormal profits rise from $4.5 \%$ to $7.9 \%$ for the two groups. However, the most dramatic effect of trading volume can be observed from the trades of investment bankers. When the investment banks trade small volumes, abnormal returns after one year equals about $9 \%$, which does not attain statistical significance. For larger volumes of more than 10,000 shares, banks' abnormal return rise to a whopping $25.4 \%$, and they are statistically significant at the $1 \%$ level.

Table 3 shows another interesting pattern for investment banks. When they trade smaller volumes, their abnormal returns attain statistical significance in ten days. When they trade larger volumes, their abnormal returns attain statistical significance only around 50 days and remains statistically significant for a oneyear holding period. This finding is consistent with the inference that investment bankers are not too concerned about the legal consequences of small volumes of trading but they may be more concerned about large volumes of trading. ${ }^{167}$ As a result, they may use large volumes of trading only to exploit long-lived information.

167. See, e.g., Ian Ayres \& Stephen Choi, Internalizing Outsider Trading, $101 \mathrm{MICH}$. L. REV. 313, 398 (2002) (acknowledging the greater palatability of small volume trading). 
Eliminating Conflicts of Interest in Banks

\begin{tabular}{|c|c|c|c|c|c|c|}
\hline 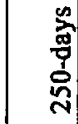 & 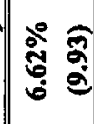 & 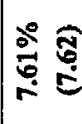 & 要 & 突 & & 商 \\
\hline 密 & 害 & 今气 & 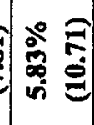 & 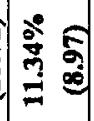 & & 㝵 \\
\hline $\begin{array}{l}n \\
\frac{\pi}{3} \\
\vdots \\
\vdots\end{array}$ & సิ & 总 & 㟢 & 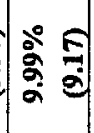 & 产 & 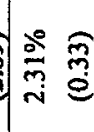 \\
\hline 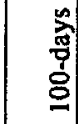 & 离 & $\begin{array}{l}\circ \\
\vdots \\
\vdots \\
ن\end{array}$ & 密 & 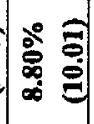 & & 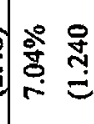 \\
\hline 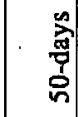 & 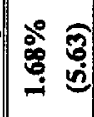 & 赵 골 & $\stackrel{\circ}{\circ}$ & 高 & & 产 \\
\hline ) & 今ั & 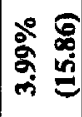 & $\mid \begin{array}{cc}0 & 0 \\
3 & 0 \\
0 & 0\end{array}$ & 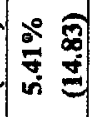 & & 总 \\
\hline 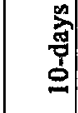 & 突 & 蛋 & 容 & 通 & $\stackrel{\circ}{\stackrel{\circ}{\circ}}$ & 商 \\
\hline 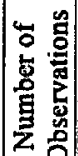 & 空 & 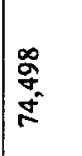 & $\frac{\infty}{0}$ & $\frac{\infty}{\frac{\infty}{m}}$ & 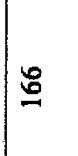 & 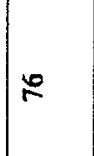 \\
\hline & 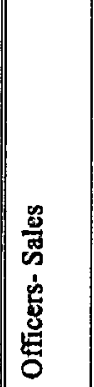 & 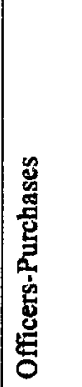 & 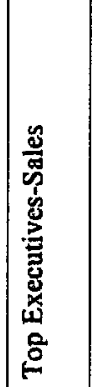 & 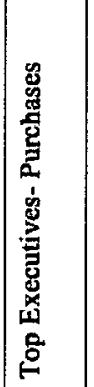 & 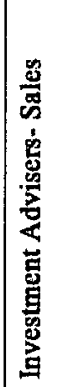 & 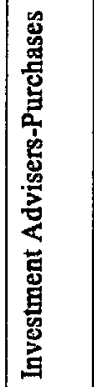 \\
\hline
\end{tabular}


Next, we investigate profitability of sales and purchases separately. To focus more narrowly on information events, we also restrict our sample to large volumes of trading only. Our evidence is shown in Table 4.

For both officers and top executives, both sales and purchases display abnormal profitability. For officers, abnormal profitability equals about $6.6 \%$ and $7.6 \%$, for sales and purchases, respectively. For top executives, abnormal profitability equals about $7.1 \%$ and $12.2 \%$, for sales and purchases, respectively. Hence, for both officers and top executives, purchases tend to be somewhat more profitable than sales.

For investment bankers, this pattern is reversed. When they sell a large volume of shares, abnormal profitability rises to $36.4 \%$, which is very large and highly significant. When investment bankers buy a large volume of shares, abnormal profitability rises only to $2.7 \%$, which is not significant. Thus, our evidence indicates that investment bankers tend to trade and profit more on adverse, material, non-public information. This finding suggests that the bankers may be hired to help with some developing problems with the client firms. As a result of this, they learn about the developing problems and the data suggests they trade on this information.

If investment bankers trade on material, non-public adverse information about their client firms, the banks may help disseminate this adverse material information more publicly and lead to further negative consequences for their clients. This kind of proprietary trading can be detrimental to the bankers' client firms. Thus, it becomes important to enforce the Volcker Rule to prohibit this kind of proprietary trading. The Volcker Rule can help reduce the conflicts of interest between the banks and their client firms.

Finally, we investigate whether the profitability of proprietary trading by the bankers has changed over time. For this purpose, we focus on the post-SOX period (2002 to 2016) only. These results are shown in Table 5.

Our evidence shows that if anything, the abnormal profitability of the proprietary trading by the banks has increased during the most recent period. The one-year abnormal profits during the 2002 to 2016 period exceed $40 \%$ for large sales by the banks. This amount is both large and statistically significant at the $1 \%$ level. This evidence is consistent with the inference that there is no decline in the profitability of trading by investment advisers over time, indicating that the concerns about proprietary trading continues to this day. 


\begin{tabular}{|c|c|c|c|c|c|c|c|}
\hline 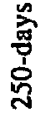 & $\begin{array}{ll}0 & 8 \\
3 & 8 \\
3 & 0\end{array}$ & 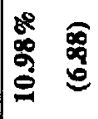 & 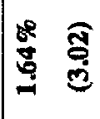 & 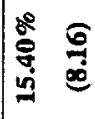 & 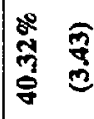 & 尔 & $\frac{9}{0}$ \\
\hline 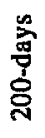 & 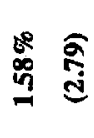 & \begin{tabular}{l}
25 \\
\multirow{2}{2}{} \\
2
\end{tabular} & 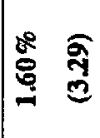 & 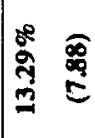 & 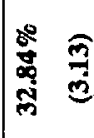 & 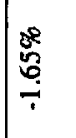 & 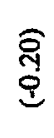 \\
\hline 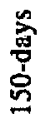 & 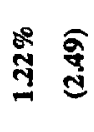 & \begin{tabular}{ll}
0 & $\overline{3}$ \\
\hdashline & 3 \\
$\infty$ & $=$
\end{tabular} & 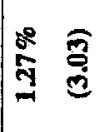 & \begin{tabular}{ll}
\multirow{2}{*}{} & $\widehat{a}$ \\
& $E$
\end{tabular} & 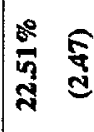 & 哭 & $\begin{array}{l}5 \\
\stackrel{9}{9}\end{array}$ \\
\hline 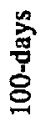 & 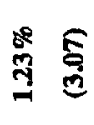 & $\begin{array}{ll}2 & 2 \\
\text { 군 } & 5\end{array}$ & $\begin{array}{ll}2 & 0 \\
3 & 0 \\
3 & 0\end{array}$ & $\begin{array}{ll}0 & 0 \\
n & 0 \\
0 & 0 \\
0 & 0\end{array}$ & $\begin{array}{ll}g & E \\
g & \Xi\end{array}$ & $\frac{8}{0}$ & 욜 \\
\hline 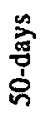 & 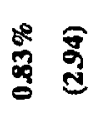 & 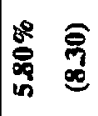 & 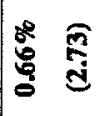 & $\begin{array}{ll}8 & 0 \\
5 & 0 \\
n & 0\end{array}$ & $\begin{array}{cc}8 \\
0 \\
0 & 0 \\
0 & 0\end{array}$ & : & త్ \\
\hline 弯 & 总 & $\begin{array}{ll}\stackrel{0}{2} \\
\text { N } \\
\text { in } \\
\text { in }\end{array}$ & 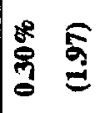 & $\begin{array}{ll}0 & 5 \\
0 & 9 \\
0\end{array}$ & 疍 & 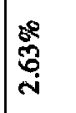 & $\stackrel{\overparen{0}}{0}$ \\
\hline 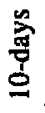 & 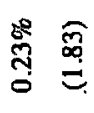 & 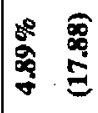 & 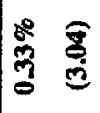 & 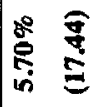 & $\underset{0}{5}$ & 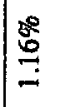 & है \\
\hline 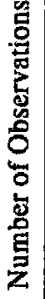 & $\begin{array}{l}\frac{ \pm}{\pi} \\
\frac{\pi}{0}\end{array}$ & $\begin{array}{l}\vec{m} \\
\vec{n}\end{array}$ & 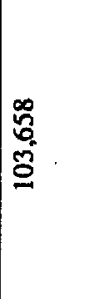 & $\begin{array}{l}\text { 苔 } \\
0 \\
\vdots \\
\vdots\end{array}$ & I & $\bar{q}$ & \\
\hline & 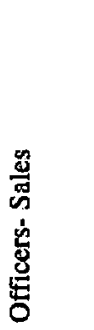 & 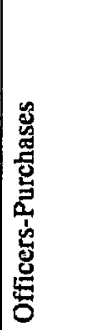 & 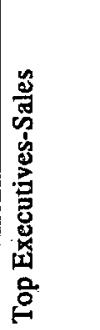 & 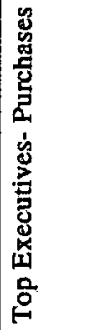 & 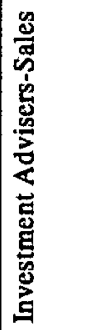 & 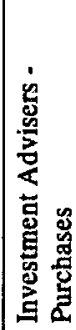 & \\
\hline
\end{tabular}




\section{Conclusion}

In this Article we investigate whether the Volcker Rule has the potential to reduce or eliminate the potential conflicts of interest between the banks and their client firms. In general, the type of information banks use to trade is confidential. Consequently, it is not possible to test the potential contribution of the Volcker Rule.

We overcome these difficulties by exploiting a unique data set that contains banks' proprietary trades when they attain temporary insider status in their client firms. Banks attain insider trading status and become subject to insider trading reporting requirements and trading restrictions when they are hired to provide financial advice to their clients. They report these trades on Forms 3,4 , and 5 , alongside other insiders. Using empirical data reported by the banks themselves, we demonstrate that banks can and do access important, private, material information about their clients and the data suggests they trade on this information. Furthermore, our evidence indicates that banks and other investment advisers typically trade on and make profits from adverse information about their clients. Hence, our evidence is designed to uncover the importance of the private information banks acquire as part of their intermediary and advisory role.

On average, we find that the inside information that banks acquire and trade on is highly valuable, allowing the banks and investment advisors to earn more than $25 \%$ on their proprietary trades. Furthermore, we find that relaxation and elimination of the Glass-Steagall restrictions allowed the banks and investment advisors to trade more frequently and earn greater amounts of abnormal profits. Since 2002, banks and investment advisors tend to trade and earn more than $40 \%$ abnormal profits from adverse information about their client firms. The nature of the information that the banks and investment advisors trade on is adverse (negative) information about their client firms. Hence, our empirical evidence demonstrates that banks profit using adverse information about their client firms, exactly as envisioned by the Volcker Rule. Trading on adverse information about their client firms suggests that banks and investment advisers do not worry about potential conflicts of interests. By trading on adverse information, the banks and investment advisers publicize their clients' financial problems, prematurely depress their stock prices, and potentially make it more difficult for the client firms to solve their financial problems. All these considerations are consistent with potential conflicts of interest between the banks and other investment advisers and their client firms.

Consequently, we provide important empirical support for the idea that an added benefit of implementation of the Volcker Rule would be to eliminate the incentives to trade on material, non-public information about their clients that benefit the banks to the detriment of their clients, by eliminating proprietary trading by banks. Thus, we argue that implementing the Volcker Rule would also 
help contain some the current conflicts of interest present in the banking system introduced by the elimination of Glass-Steagall restrictions.

In spite of these benefits, the future of the Volcker Rule is currently uncertain. Recent legislation introduced by the Trump administration is directed at repealing Dodd-Frank and eliminating the Volcker Rule altogether, instead of implementing it. The Financial CHOICE Act, passed in the House in June 2017, includes a repeal of the Volcker Rule in its effort to "[c]reat[e] [h]ope and [o]pportunity for [i]nvestors, [c]onsumers and [e]ntrepreneurs." "168 House Financial Services Committee Chairman Jeb Hensarling claimed the repeal would pave way for "economic growth for all; bank bailouts for none."169 Yet our evidence indicates that instead of repealing, implementing the Volcker Rule expeditiously would have the added benefit of reducing conflicts of interest. Based on our evidence, we recommend strong enforcement of the Volcker Rule.

168. The Financial CHOICE Act, H.R. 10, 110 th Cong. (2017); The Financial Choice Act Executive Summary, HOUSE COMM. ON FIN. SERV., http://financialservices.house.gov/uploadedfiles /financial_choice_act_executive_summary_final.pdf [http://perma.cc/TD5E-XBVY].

169. Geoff Bennett, House Passed Bill Aimed at Reversing Dodd-Frank Financial Regulations, NAT'L PUB. RADIO (June 8, 2017), http://www.npr.org/2017/06/08/532036374/housepasses-bill-aimed-at-reversing-dodd-frank-financial-regulations [http://perma.cc/ YEC9-MLB7]. 
